NBER WORKING PAPER SERIES

\title{
HOME PRODUCTION AND THE MACRO ECONOMY- SOME LESSONS FROM POLLAK AND WACHTER AND FROM TRANSITION RUSSIA
}

\author{
Reuben Gronau \\ Working Paper 12287 \\ http://www.nber.org/papers/w12287 \\ NATIONAL BUREAU OF ECONOMIC RESEARCH \\ 1050 Massachusetts Avenue \\ Cambridge, MA 02138 \\ June 2006
}

A first draft of this paper was presented at the SITE conference on "The Nexus between Household Economics and the Aggregate Economy", August 2005. Avivit Yemin and Riki Eliyahu gave excellent research assistance. Special thanks are reserved for Andrei Rachkov who helped me in the final stages of the empirical work. The views expressed herein are those of the author(s) and do not necessarily reflect the views of the National Bureau of Economic Research.

C2006 by Reuben Gronau. All rights reserved. Short sections of text, not to exceed two paragraphs, may be quoted without explicit permission provided that full credit, including $\odot$ notice, is given to the source. 
Home Production and the Macro Economy-Some Lessons from Pollak and Wachter and from Transition Russia

Reuben Gronau

NBER Working Paper No. 12287

June 2006

JEL No. D13, E32, J22, P36

\begin{abstract}
$\underline{\text { ABSTRACT }}$
Recent years witnessed a flourishing of literature on the implication of shifts from home- production to market production on the macro economy, and in particular, the real business cycle. This literature employs calibration techniques to emulate the fluctuations in market output, labor and capital inputs and productivity over the business cycle, assuming a representative consumer and using stylized parameters of the substitution elasticity between home and market goods, and of the home production function. This paper argues that the parameters used in this literature cannot be verified empirically because of econometric identification problems. Furthermore, using data from the late 90s from transition Russia, it is argued that one cannot capture the fluctuation between the home and the market by using a representative consumer, since there is a distinct difference between males and females in their reaction to loss of employment: men shift most of the time released from market work to leisure while women divide it almost equally between work at home and leisure. Finally it is shown that the switch from a controlled economy to a market economy resulted in significant increase in home productivity and an increase in the free time enjoyed by both Russian men and women.

Reuben Gronau

Department of Economics

Hebrew University

Mount Scopus, Jerusalem 91905

ISRAEL

and NBER

msreuben@mscc.huji.ac.il
\end{abstract}




\section{Home Production and the Macro Economy-}

Some Lessons from Pollak and Wachter and from Transition Russia.

\section{A. Introduction}

The recognition that home production plays, even in developed economies, an important role in macroeconomic activity antedates Becker's 1965 seminal paper by at least two decades. In his magnum opus "National Income and Its Composition, 1919-1938" Kuznets (1944) estimated that home production constitutes almost a third of GNP, admitting that this crude value is an underestimate of the true share ${ }^{1}$. Becker's paper triggered several studies that tried to refine this estimate ${ }^{2}$, but its main impact was on the microeconomic analysis of household behavior and the economics of human resources. The balance started to shift with Becker's 1987 AEA presidential address (1988), where he pointed out the important implications of family economics and home production for growth and the macro economy. The challenge was taken up by Benhabib et.al. and by Hercowitz and Greenwood 1991 studies of the real business cycle (RBC). The two teams enlisted shifts from the market to home production to explain some irregularities in the traditional model of the RBC, and this has become the theme of several sequels. The 1991 papers signaled the start of a flood of papers invoking home production to explain a wide range of macro phenomenon: capital formation, growth, development and the welfare cost of inflation. Our paper tries to evaluate the new macro literature from an (old-fashioned) micro viewpoint.

The new generation of studies is characterized not merely by its wide scope of topics, but also by a change in research strategy. Whereas the first generation of micro studies avoided, by and large, specifying the home production's technology, the new macro studies are based on an explicit calibrations of the

\footnotetext{
${ }^{1}$ Kuznets estimate relate to 1929 . His estimate includes the value of home services of full-time housewives and the capital services of home durables other than houses.

${ }^{2}$ The studies are discussed in detail in my 1986 and 1997 surveys.
} 
home production function and the household preferences over work and goods, using stylized estimates of the parameters of the these functions. Though several authors bemoan the shaky basis of these parameters, only little has been done to correct this shortcoming ${ }^{3}$.

It sometimes seems that in the rush of discovering new applications macroeconomists have overlooked Pollak and Wachter's (1975) warning concerning the restrictive nature of Becker's tool of analysis. Pollak and Wachter point out that in the absence of an explicit measure of home output, the standard procedures of estimation of the home production function are inapplicable unless one is ready to assume that home production is subject to constant returns to scale and that work at home does not generate any direct utility. It will be shown that when these assumptions are not satisfied serious problems of econometric identification arise, problems that have been ignored in the new literature (and specifically in the empirical studies).

A second feature distinguishing the new literature from the old one is its approach to data availability. While micro analysts tested their hypotheses using detailed cross sections of time budget data, no attempt has been made to reconcile the new macro theory with data on the aggregate economic activity at home. In this case, however, one cannot blame the researchers. The time series on the evolution of home production in the advanced economies is just not available. In the U.S, for example, only five nationally representative time budget studies have been conducted over the last forty years, and the data on the changes in home production and work at home time has not yet been summarized $^{4}$. Nowhere is the data scarcity more acute than in the field of research that started the new trend - the study of the business cycle. The only component of the time budget observed fluctuating over the business cycle is market work. The short-term fluctuations of home production remain unobserved, rendering much of the new work to be of a speculative nature. One team of researchers (Ingram, Kocherlakota and Savin, 1997) expressed a

\footnotetext{
${ }^{3}$ McGrattan, Rogerson and Wright (1991) and Rupert, Rogerson and Wright (1995) are the exception.

${ }^{4}$ The first study trying to establish the major trends in leisure and work at home for the last four decades is still in the writing (Aguiar and Hurst, 2006).
} 
common plight when they titled their paper "Using Theory for Measurement: An Analysis of the Cyclical Behavior of Home Production".

Unfortunately, this limitation is hard to overcome. Even countries that are blessed with more detailed data on the allocation of time lack information on changes in the allocation of home time over the business cycle. This scarcity forces us to search for answers in an uncommon place - Russia during the transition period.

The Russian economy went in the last 15 years through one of the most tumultuous periods experienced by a modern economy since the early $30 \mathrm{~s}$. Home production (and specifically tending one's garden) has been claimed to be a major channel of escape from the deteriorating market conditions. Fortunately, Russia is unique in having a four-year panel, taken in the midst of the depression, on the allocation of time. Hence the Russian experience can serve as an indicator (perhaps, an upper bound) for changes taking place in more advanced economies during recessions.

The analysis of the Russian data is of interest by itself. The time budget of the typical Soviet Russian household thirty years ago reflected the burden imposed by a centrally controlled, producer-oriented, regime on the home sector. It has been claimed (Robinson and Godbey, 1997) that the last phases of the Soviet era witnessed an alleviation of this burden and an increase in the free time of the average Russian household, but that this trend has slowed down in the early 90s. It is worse exploring whether this halt was temporary or whether it lasted throughout the transition period.

The paper opens with a short survey of the new macroeconomic literature. The survey is followed by a general outline of a three-way allocation of time model of work in the market, work at home and leisure, and examines some of its restrictions in light of the Pollak-Wachter critique. The implications of these restrictions for the macro literature are discussed. A section describing the Russian data is followed with the analysis of these data. The final section discusses the lessons one can derive from the Russian experience concerning 
the changes in the allocation of time over the business cycle, and their implication for the new macro literature on the topic.

\section{B. Home Production and the Macro Economy- A Literature Review}

In his 1944 study Kuznets noted "in the shorter term cyclical fluctuations, expansion and contraction in general business activity mean expansion and contraction in the importance of activities eventuating in a marketable product relative to those within the family. It is especially noted that during severe depressions a drastic contraction in employment and incomes is accompanied by a significant expansion of activities within the household". Kuznets was worried of the implications of the substitution between market and home activities for the accuracy of his measurement of total economic activity. The motivation of the new macro literature is somewhat different, and has been triggered by its failure to explain the fluctuations in economic activity (the RBC) using a standard growth theory model subjected to technological shocks (Cooley and Prescott, 1995).

Using stylized parameters to examine to what extent the standard growth models can mimic the true time series data it was noted that the statistics generated by the models failed to capture the volatility of output, investment, consumption, and market work hours and the correlations between work hours and productivity and between market and household investment ${ }^{5}$. Benhabib et.al. (1991), recognizing the importance of household production in overall economic activity, and noting the low intertemporal substation of leisure, tried to improve on the performance of the model by introducing another margin of substitution, namely the substitution between market and home goods triggered by wage changes.

\footnotetext{
${ }^{5}$ According to Greenwood, Rogerson and Wright (1995) output is found to be less volatile in the model than in the data, investment in the model is too volatile, and consumption is not volatile enough relative to output. Focusing on the labor market, hours worked, according to the model, are not volatile enough relative to either output or productivity. Finally, the model generates wrong correlation signs: hours worked and productivity are highly correlated in the model but not in the data; and the market and household investment series are positively correlated in the data but not in the model.
} 
Benhabib et. al study had several sequels (Greenwood, Rogerson and Wright, 1995; McGrattan, Rogerson and Wright, 1997; Ingram, Kocherlakota and Savin, 1997; Perli, 1998; Campbell and Ludvigson, 2001), and so had Greenwood and Hercowitz 1991 paper focusing on capital formation over the business cycle (Gomme, Kydland and Rupert, 2001). The 1991 papers were followed by several studies invoking home production and employing the RBC calibration technique to explain a wide range of other macro phenomenon: growth (Einarsson and Marquis 1997), development (Parente, Rogerson and Wright 2000; Gollin, Parente and Rogerson 2004) and the welfare cost of inflation (Marquis 2001).

The expansion of the model called for the specification of the preference function, defined over market and home goods, the household production function and the structure of technological shocks in the market and the household sectors. Most studies followed Benhabib et. al.'s lead assuming a CES preference function, differing in their specification of the production function and the structure of shocks. A critical role in the calibration of the model is assigned to the elasticity of substitution between market and home goods. In the absence of any prior information on this parameter, the studies relied on intuition, using estimates that vary between 1.66 and 5.0 .

Only few of the studies bothered to estimate this elasticity of substitution, the exceptions being McGrattan, Rogerson and Wright (1997) and Rupert, Rogerson and Wright (1995). The first study uses time series quarterly data for the period 1947-1992. But in the absence of information on the key variablework at home, it is difficult to evaluate the validity of its results. The Rupert et. al. paper stands out in being the only empirical paper of the new generation using a cross-section sample containing information (though imperfect) on time spent in work at home.

The authors use the standard framework: preferences are defined as a function of consumption and work time, where consumption is a CES function of market and home goods, and work is a CES function of market work and work at home. An attempt is made to estimate all three parameters: the substitution 
elasticities between market and home goods, and between market and home work, and the production elasticity of home goods. The failure of this attempt leads the authors to estimate a less ambitious model, where work at home and work in the market are assumed to be perfect substitutes and where the production elasticity of home goods is set at an arbitrary value, leaving only one parameter to be estimated - the elasticity of substitution between market and home goods.

Given the crucial role the elasticity of substitution between market and home goods plays in the new macro models, and the wide range of estimates used in the calibration, it is worth enquiring whether Rupert's failure to estimate the full model should be blamed on faulty data or whether it suggests a more fundamental problem. A corollary relates to the estimation of the restricted model, and how dependent is the estimate of the elasticity of substitution on the restrictions imposed on the other two parameters.

\section{$\underline{\text { C. The Specification and Identification of the Household Production Model }}$}

An expansion of the model of the allocation of time from a two "sector" model (i.e., market work and home time) to a three-way allocation (market work, work at home and leisure) involves several complications. The simple preference function defined over two variables - goods and home time, has to be replaced by a specification of a preference function defined over two types of goods (market and home goods) and three time uses. In addition, it requires the specification of the home production function ${ }^{6}$.

Formally, the preference function is $\mathrm{U}=\mathrm{U}\left(\mathrm{X}_{\mathrm{m}}, \mathrm{X}_{\mathrm{h}}, \mathrm{T}_{\mathrm{m}}, \mathrm{T}_{\mathrm{h}}, \mathrm{L}\right)$, where $\mathrm{X}_{\mathrm{m}}$ denotes market goods, $\mathrm{X}_{\mathrm{h}}$ - home goods, $\mathrm{T}_{\mathrm{m}}$ - market time, $\mathrm{T}_{\mathrm{h}}$ - work at home time and $\mathrm{L}$ - leisure. The home production function is $\mathrm{X}_{\mathrm{h}}=\mathrm{F}\left(\mathrm{K}_{\mathrm{h}}, \mathrm{T}_{\mathrm{h}}\right)$, where $\mathrm{K}_{\mathrm{h}}$ denotes home capital. The constraints confronting the person are the budget

\footnotetext{
${ }^{6}$ A more sophisticated multi-period version also calls for the specification of the capital accumulation process. Another complication involves the incorporation of multi-person decision making in the model.
} 
constraint $\mathrm{X}_{\mathrm{m}}=\mathrm{wT}_{\mathrm{m}}+\mathrm{r} \mathrm{K}_{\mathrm{m}}$, where $\mathrm{w}$ is the real wage rate, $\mathrm{K}_{\mathrm{m}}$ - market capital and $r$ the real interest rate, and the time constraint $T_{m}+T_{h}+L=1$. Assuming that the capital inputs $\mathrm{K}_{\mathrm{i}}$ are exogenously given, the first order conditions for an interior solution (i.e., $\mathrm{T}_{\mathrm{m}}>0, \mathrm{~T}_{\mathrm{h}}>0$ ) are

$$
\left(\mathrm{U}_{\mathrm{L}}-\mathrm{U}_{\mathrm{Tm}}\right) / \mathrm{U}_{\mathrm{Xm}}=\mathrm{w} \text { and }\left(\mathrm{U}_{\mathrm{L}}-\mathrm{U}_{\mathrm{Th}}\right) / \mathrm{U}_{\mathrm{Xh}}=\mathrm{F}^{\prime} \text {. }
$$

Combining the two equations, one obtains the familiar factor demand equation

$$
\Pi \mathrm{F}^{\prime}=\left[\left(\mathrm{U}_{\mathrm{L}}-\mathrm{U}_{\mathrm{Th}}\right) /\left(\mathrm{U}_{\mathrm{L}}-\mathrm{U}_{\mathrm{Tm}}\right)\right] \mathrm{w},
$$

stating that the value of marginal productivity of work at home equals the "shadow" price of time at home. $\Pi=\left(\mathrm{U}_{\mathrm{Xh}} / \mathrm{U}_{\mathrm{Xm}}\right)$ denotes the "shadow" price of home goods, F' is the marginal productivity at home, and the "shadow" price of time is corrected for the differential in direct utilities of work in the market compared with work at home $\left.\left(\mathrm{U}_{\mathrm{L}}-\mathrm{U}_{\mathrm{Th}}\right) /\left(\mathrm{U}_{\mathrm{L}}-\mathrm{U}_{\mathrm{Tm}}\right)\right]$.

Unfortunately, the model suffers from too many parameters and too few variables allowing for identification. Three out of the four terms in the factor demand equation are unobserved (the "shadow" price of home goods, the marginal productivity of work at home, and the price of time correction factor), limiting the applicability of this equation for empirical research. Thus, changes in the observed variable, the wage rate, can be used to trace the parameters of any of the unobserved terms, but only if the parameters of the other two unobserved terms are arbitrarily restricted.

The econometric identification problem can be traced to Pollak and Wachter's (1975) criticism of the household production model. Pollak - Wachter point out the limitations of Becker's model, given that the output of the production process (the "commodity" in Becker's terminology) and its price are unobserved. To separate price effects from income effects one has to assume that the "shadow prices" of the commodities are insensitive to the level of production, and this is true only if home technology is subject to constant returns to scale, and if the production process does not convey utility by itself 
(i.e., if the welfare derived from a commodity is independent of the way it was produced) ${ }^{7}$.

To avoid this problem Gronau (1977) assumed $X=X_{m}+X_{h}$ and $T=T_{m}+T_{h}$, i.e., home goods and market goods are perfect substitutes $\mathrm{U}_{\mathrm{Xm}}=\mathrm{U}_{\mathrm{Xh}}=\mathrm{U}_{\mathrm{X}}$, (and hence $\Pi=1$ ) and the same is true for work at home and work in the market $\mathrm{U}_{\mathrm{Tm}}=\mathrm{U}_{\mathrm{Th}}=\mathrm{U}_{\mathrm{T}}$. This simplification yields the dual condition for an interior optimum $\left(U_{L}-U_{T}\right) / U_{X}=F^{\prime}=w$. The existence of two separate margins allows the tracing of the slope of the production function and the contours of the indifference curve between work time and goods. In this scheme the choice of leisure (or alternatively, work time) and goods is governed by preferences, and the allocation of work time between home and market is determined by technology ${ }^{8}$. Putting it in graphic terms (figure 1), exogenous changes in the wage rate allow one to trace the demand for home time (i.e., the value of marginal productivity of $T_{h}$ ).

The "price" Gronau had to pay for attaining identification of the home production function was giving up on the estimation the psychic income component (i.e., the utility component) associated with work at home. This shortcoming seems particularly disturbing in the case of childcare.

Graham and Green (1984) were the first to try and remedy this shortcoming. More recently Kerkhofs and Kooreman (2003) suggested an ingenious solution. Their preference function is defined over goods $(\mathrm{X})$ and leisure $\left(\mathrm{L}^{*}\right)$, preserving the assumption of perfect substitution between home and market goods $\mathrm{X}=\mathrm{X}_{\mathrm{m}}+\mathrm{X}_{\mathrm{h}}$ but replacing the assumption of perfect substitution between home and market work by the assumption that work at home generates some direct utility $\mathrm{L}^{*}=\mathrm{L}+\mathrm{g}\left(\mathrm{T}_{\mathrm{h}}\right)$.

Rupert et.al.'s model ignores the Pollak - Wachter warning. Their attempt to extract all three parameters was, therefore, doomed for failure, and their estimate of the elasticity of substitution between home and market goods, in

\footnotetext{
${ }^{7}$ The authors define this case as a case of "jointness": "Jointness is pervasive because time spent in many production activities is a direct source of utility as well as an input into a commodity."(p.256)

${ }^{8}$ Since the allocation of work time is governed solely by home technology it is insensitive to other nonlabor resources. This conclusion allowed Gronau to test his formulation.
} 
their more restrictive scheme, depends heavily on the arbitrarily chosen value of the elasticity of home output with respect to work at home.

The identification problem is demonstrated in figure 2. $\Pi$ F' describes the value of marginal productivity at home, assuming diminishing marginal productivity. However, when home and market goods are not perfect substitutes an expansion in home production entails a decline in its shadow price $\Pi$. The observed curve $\mathrm{D}_{\mathrm{Th}}$ is hybrid of the value of marginal productivity and the demand for home goods ${ }^{9}$. Assuming perfect substitution between home and market time $T=T_{m}+T_{h}$, the shadow price of time $w$ is insensitive to $T_{h}$ and one can trace the $\mathrm{D}_{\text {Th }}$ curve, but one cannot separate the changes in F' from the changes in $\Pi^{10}$. The two extreme cases that allow identification are the case where $\Pi$ is constant (adopted by Gronau) and the case where F' is constant (an assumption made by Benhabib et. al.).In the first case one can identify the marginal productivity function F', and in the second case- the demand for home goods (i.e., the elasticity of substitution between home and market goods).

The distinction between changes in the marginal productivity of work at home and changes in the shadow price of home production bears also on the measurement of the changes in home output and welfare. When $\Pi$ is constant, and the curve $\mathrm{D}_{\mathrm{Th}}$ reflects the value of marginal productivity of work at home, home output is measured as the area under the curve, and the change in home output as a result of the decline in wages is depicted by the area $\mathrm{T}_{\mathrm{h} 0} \mathrm{ABT}_{\mathrm{h} 1}$. On the other hand, when it is assumed that the marginal productivity is constant, the change in real home output is merely $\mathrm{T}_{\mathrm{h} 0} \mathrm{EBT}_{\mathrm{h} 1}{ }^{11}$.

\section{Transition Russia - Background and the RLMS Data}

It is perhaps ironic that the new macroeconomic literature on home production has very little to say about work at home. The central stage is occupied by the

\footnotetext{
${ }^{9} \mathrm{D}_{\mathrm{Th}}$ is the analogue of the industry-wide demand for factors of production.

${ }^{10}$ If one assumes that $T_{h}$ generates direct (diminishing) utility the shadow price of time increases with $\mathrm{T}_{\mathrm{h}}$, complicating the identification problem even more.

${ }^{11}$ When the $\mathrm{D}_{\mathrm{Th}}$ curve is iso-elastic $\mathrm{T}_{\mathrm{h}}=\mathrm{Bw}^{-\eta}$, the percentage change in real output is (1- $\eta$ ) $\ln \mathrm{w}$ in the first case, and $-\eta \mathrm{d} \ln \mathrm{w}$ in the second.
} 
changes in market work over the business cycle, the sub-plot deals with fluctuations in home durables investment, and work at home is delegated to the role of a behind-the-stage actor, explaining the behavior of the other series. In second thought this is not surprising. After-all macro deals with economic aggregates, and there just exists no reliable information on the aggregate labor inputs in the home sector. The decision to leave the economic activity in this sector outside the national accounts doomed the labor inputs to remain unreported. There are no official time series in any of the advanced Western economies concerning work-at-home, and there are too few cross sections studies to construct an annual series, from which one can derive the cyclical variation of work at home. Necessity leads us, therefore to "strange" places - to search for clues in the behavior of the Russian economy during the transition period.

The transition of the East European economies from a centrally planned economy to a capitalist-style regime was a painful process. Nowhere was it more painful than in Russia itself. Russian GDP fell by over 40 percent before it started to pick-up following the financial crisis of 1998, and real wages dropped at a similar rate (World Bank, 2003). The dramatic changes left their traces, naturally, on the labor market. In the period 1992-1998 Russian labor force participation rates declined from 70 to 61 percent, unemployment rates more than doubled (from 3.6 to 8.1 percent), so that the drop in the employment rate was even sharper.

The World Bank team that studied the upheaval in the Russian labor market (2003) argue that over one half of the decline in employment rate can be explained by a switch from market production to home production, and specifically subsistence agriculture for own consumption. This shift was not confined to rural areas, and almost one half of the people engaged in subsistence agriculture lived in urban areas ${ }^{12}$. Robinson and Godbey (1997)

\footnotetext{
${ }^{12}$ An early draft of the World Bank report is contained in Earl and Sabrianova (2001). These researchers were not the only ones who recognized the importance of the "informal sector" in the Russian economy and its implications for the Russian market. Kolev (1998) estimated the labor supply
} 
who pursued the Russian life style since the mid-sixties observe a similar trend and claim that the increased gardening activity in the early $90 \mathrm{~s}$, and a parallel change in shopping activity, resulted in a slow down of this trend of increased leisure time enjoyed by the Russian women since $1965^{13}$. It is of interest to explore whether the interruption in the trend is temporary, or whether the transition process resulted not merely in the erosion of material wealth but also in the decline of free time.

The study of the allocation of time in Russia during the transition period is of interest also for other reasons. The sharp decline in market output during that period reflects the low productivity of the market sector in a centrally controlled regime. Less well documented (but easily observed) was the low productivity of the home sector. Scarcity of consumer goods and an inefficient retail sector made search and queues an inseparable part of daily life in the old regime. Outdated home equipment resulted in daily tasks lasting longer than in the West. Low rates of car ownership and high labor force participation rates may have resulted in longer commuting time ${ }^{14}$. Finally, low productivity in the market due to inefficient work habits may carry over also to the home. While the shift from market to home production is perhaps important in the short run, the increased productivity at home and the increased leisure at the expense of home-work time has more long-lasting implications for the quality of life in Russia. The substitution between work and leisure is, therefore, the second focus of this empirical section.

The study takes advantage of a unique body of data - the Russian Longitudinal Monitoring Survey (RLMS) which incorporated in four of its rounds (covering

\footnotetext{
in the informal economy, and Kim (2003) estimates that 27 percent of GDP in 1997-98 originated in that sector.

${ }^{13}$ The Robinson and Godbey (1997) findings are based on the time-diaries of 500 adults. The survey was conducted in January 1995 in Pskov, a city chosen as a representative city of Russia. Given the differences in coverage and the method of data collection it is difficult to compare the Pskov results with those reported in this paper. According to the Robinson and Godbey results leisure time (including personal care) went down in the period 1986-1995 for almost every employment group (it did not change for employed women). The results for the sample as a whole are heavily affected by the low employment rate in the Pskov sample (66 percent for men, and 54 percent for women).

14 Commuting time depends on the geographical distribution of housing and work places. In a centrally planned economy households have little control on the location of either one of these places, resulting in greater commuting time. The low rate of suburbanization may have the opposite effect.
} 
the years 1994-1998) questions on time-use ${ }^{15}$. What makes these data unique is the panel nature of the survey. It is the first time that the allocation of time is analyzed in this framework. The high transition probabilities from employment to unemployment and exit from the labor force in Russia in the period covered by the survey should shed new light on the substitution between time uses, which the simple cross-section studies cannot reveal.

Another important feature of the data is the household aspects. The questionnaire was administered to all household members, allowing a closer investigation of the role of household interactions in the determination of the individuals' allocation of time.

The second phase of the Russian Longitudinal Monitoring Survey (RLMS) started in 1994 and lasted for 7 rounds till 2002. The first 4 rounds (rounds V to VIII covering the years 1994-1996 and 1998) included a supplement (supplement $\mathrm{O}$ ) on the use of time ${ }^{16}$. The questions related to the previous week, and each adult in the household was asked to recall how much time he spent on work, commuting to work, working on the land (or garden), purchasing food, preparing food, cleaning the apartment, laundry, taking care of children (own children or others), caring for parents, and sleep.

Given the claim of a high degree of substitution between work in the market and work in subsistence agriculture, special attention was paid to the time spent on work on one's land. Unfortunately, the survey was conducted during the winter months ${ }^{17}$. The harsh Russian weather has clearly a negative effect on the supply of "garden work", but this will be also true for large parts of North America and Northern Europe. Furthermore, as the 1999 Russian Labor Force

\footnotetext{
${ }^{15}$ Questions on time use were asked also in earlier rounds of the survey. Unfortunately these data are not comparable with later rounds because of changes in sampling design. Equally unfortunate was the decision to terminate this part of the study in 1998.

${ }^{16}$ The survey was not conducted in 1997 the year preceding the great financial crisis. In 1998 the survey was conducted 2-5 months after the crisis reached its peak.

${ }_{17}$ The interviews in round V took place during November and December 1994, round VI from October to December 1995, round VII - during the same months in 1996, and round VIII from October 1998 to January 1999. Another word of caution: The RLMS is not a random sample of the Russian population, because the different regions are not represented proportionally in the sample. The effect of this shortcoming in the sample design on our results is not clear.
} 
Survey indicates, the number of people reporting employment in subsistence agriculture in November was far from negligible, and was almost one half that of August (World Bank, 2003, Table I.12). To overcome this shortcoming of the time use data it was supplemented by the household's estimate of its value of household production.

The RLMS panel sampling unit is the dwelling unit and not the household. Round VII was the first to depart from the original protocol, and an attempt was made to follow households who changed apartments (RLMS, 1997). Still, given the low mobility of the Russian population, the attrition due to mobility is not serious. Attrition affects more the metropolitan areas (Moscow and St. Petersburg) and the better educated and better endowed parts of the population. To the extent that these groups are less prone to unemployment, their under-representation should result in an upward bias in the estimation of the degree of substitution between home and market production.

Previous studies have shown little systematic effect of economic variables on the time use of single people. Consequently, most of this study is confined to married couples in the age group 18-60.

\section{E. First impressions}

Table 1 describes the changes in the time use patterns based on the sample means of the four rounds for the population as a whole ${ }^{18}$. It includes the information on the incidence of the activity (i.e., the probability that the person reported a positive number of hours), and on the average hours spent by those engaged in the activity. The time budget data follow the labor force surveys in reporting a significant decline in employment - the employment rate declining by one-tenth. The decline in the employment rate is the dominant factor explaining the decline of working hours (which declined by one-eighth). It is, however, worth noting that, whereas, the mean hours of work of those employed shows no explicit trend, commuting time declined steadily, saving the employed half an hour weekly. The decline of commuting time can be

\footnotetext{
${ }^{18}$ The table is based on the adult questionnaire, and relates to everyone 14 years or older.
} 
attributed to either a change in the choice of a place of work, closer to home, or to improved transportation (e.g., a greater availability of private cars).

The probability that a person works his plot or his garden fluctuated sharply over the four rounds. Gardening was reported only by $1 / 8-1 / 6$ of the adults in 1994 and 1998 and by over a quarter of those interviewed in 1995 and $1996^{19}$. The number of hours spent gardening for those engaged in the activity is, however, on the decline.

The decline in the time spent on the other housework activities (shopping for food, cooking, house cleaning and laundry) reflects the impact of the "capitalist revolution" on the Russian home and kitchen. It may be argued that the reduced time inputs reflect a decline in demand for these services, but in this case one would have expected a decline both in the incidence of these activities and in their duration. The fact that participation in these activities has hardly changed over time, and that the decline is solely in the hours spent by those engaged in the activity seems to imply an increase in productivity reducing the length of time it takes to carry out the activity. The RLMS does not cover all housework activities $^{20}$, but adding up the five activities reported in the survey the time savings are considerable - almost 4 hours a week - more than 20 percent of the time spent in 1994. The timesavings in housework (which are voluntary) exceed in magnitude those in market time (which are, at least partly, involuntary).

Parents of children less than 14 years old were asked how much time they spent caring for their children. The reports show fluctuations over the period, but no observable decline (in contrast to the time spent caring for other children). The decline in fertility is reflected, however, in a decline in incidence, resulting in 10 percent less time devoted to this activity. Perhaps the most important change in the Russian time budget is the resumption of the increase in free time. The

\footnotetext{
${ }^{19}$ The rate of participation in the gardening activity in 1998 is very similar to that reported by the Goskomstat 1999 labor force surveys for February and November (Earl and Sabrianova, 2001, Table III. 5).

${ }^{20}$ For example, it does not report the time spent on shopping for non-food items. This activity may have increased given the greater variety of goods and greater price dispersion in Russian stores.
} 
decline in hours of work in the market and at home released 6 weekly hours for leisure activities- an increase of over 10 percent. It is, of course difficult to compare the RLMS results with those of Robinson and Godbey, but taking them at face value, it looks as if the leisure time bounced back to its pretransition level, and may have even increased. In the advanced Western economies some of the increase in leisure comes at the expense of sleep. Biddle and Hamermesh, (1990) attribute this change to the sensitivity of sleep-time to material wealth - the greater availability of goods increases time scarcity and results in people cutting down on sleep, their most time intensive activity. The decline in the Russian real wage rate was clearly not conducive to this Western trend, and time spent on sleep hardly changed over the period.

Time use patterns differ by gender. Table 2 distinguishes between married men and women focusing on married couples ${ }^{21}$. The decline in employment rates in this sample is much sharper than the one reported in table 1 . The rates for men decline from 86 percent to 74 percent, and for women from 75 to 66 percent $^{22}$. The decline in employment rates is the main factor explaining the decline in the amount of time spent in the market (including commuting time) of 8 hours a week for men and 2 hours for women. The market time of employed men declined by 4 hours (the 4 -year mean is 43 hours a week), and the market hours of employed women hardly changed (fluctuating around a mean of 37.5$)^{23}$.

Married women in Russia follow the universal pattern, bearing the main responsibilities for housework and children (gardening being the only activity where husbands prevail). As a result, they are also the main beneficiaries of the increased productivity at home. The time saved in housework (6 hours) almost

\footnotetext{
${ }^{21}$ The sample of couples described in table 2 is confined to the age group 18-60. The age constraint results in the reduction of the sample (compared to the sample used in table 1) by more than one-fourth. The removal of the upper bound in the age constraint (i.e., including in the sample all couples, 18 or older) increases the sample to 1500 observations. The labor force participation rate in the "older' sample is about 10 percent lower, and the mean values for work at home and leisure are significantly higher, but the regression results (reported in tables 3-5) are hardly affected.

${ }^{22}$ Goskomstat reports a decline in the national employment rate for that period from 67 to 53 percent (Earl and Sabrianova, 2001, table III 1).

${ }^{23}$ The decline in commuting time observed in table 1 is also observed in the couples samples.
} 
equals the "time savings" of their husbands from the decline in employment. The decline in fertility added to these savings another 2.5 hours spent previously in childcare ${ }^{24}$.

In the West married men and women spend about the same time in work (Gronau and Hamermesh, 2001), men spending more time in market work and women specializing in work at home and childcare. The high participation rates of married women in Russia in the old regime and the scarcity of part-time jobs resulted in Russian married women working over one third more than their husbands ${ }^{25}$. The decline in hours worked was almost the same for women than for men (12 hours), so that the gap did not change.

Gronau and Hamermesh (2001) observe in six Western countries that married women and men have about 15.5-17 hours a day for leisure and personal care (including sleep). The average Russian woman in 1994 was not that fortunate, having only 13.3 hours $^{26}$. The addition of 11 weekly hours of non-work time brought her, however, much closer to the Western norm. In contrast, Russian married men in 1984 spent over 16 hours daily on non-work activities. The additional 12 weekly hours of free time "gained" during the transition period, places them at the top of the Western league. Married women in the West tend to sleep more than their husbands. The scarcity of free time explains the opposite pattern in pre-transition Russia. Not surprising, some of the free time gained by Russian women during the transition period was diverted to sleep.

The results in table 2 are confirmed by a detailed regression analysis based on a pooled sample of the 4 cross sections (table 3 ). The explanatory variables are the standard ones: schooling, age (and age squared), number of young children (less than 6), number of older children (6-14), and living in urban areas (a dummy variable). The results seem mostly standard in Western terms:

\footnotetext{
${ }^{24}$ The decline in work at home and childcare was much more pronounced (in absolute and relative terms) in the case of the not employed compared with the employed.

${ }^{25}$ Work includes childcare and other care.

26 The time spent on "leisure" was computed as the difference between 168 and the weekly hours reported in the time use survey. It includes time spent on personal care (beside sleep) and work at home activities not covered by the questionnaire (e.g., shopping for non-food items, administrative tasks, etc.).
} 
schooling has a strong positive effect on the number of hours spent in work in the market (slightly stronger for married women than for married men), and age has the customary inverted $\mathrm{U}$ shape effect ${ }^{27}$. Schooling has a negative effect on married women's work at home, but, surprisingly, a positive effect on married men's work at home. As a result schooling is associated with a decline in sleep and leisure both in the case of men and in the case of women.

When it comes to children, in spite of the well developed childcare facilities, Russia does not differ much from the West: It is the mothers, irrespective of their level of schooling, who bear most of the burden of childcare. The effect of an additional young child on his mother's childcare time is almost 3 times greater than the effect it his on the father. Young children in the West tend to increase the time spent by their fathers in the market, and reduce that of their mothers. Russian fathers do not seem to follow this pattern. Finally, young children cut into their parents' leisure, and again the "price" paid by the mother is significantly higher than that paid by her husband.

The regressions in table 3 incorporate also the time spent by the spouse on the activity. The results imply a strong positive correlation for all time uses. The positive correlation may be due to positive assortiative mating, complementarity in home time use or merely a positive correlation in response errors. In either case we do not observe at the individual household level patterns of substitution in home time use between the husband and wife's time.

Finally, the regressions confirm the trend in the allocation of time: a steady decline of the time spent in work in the market and work at home, and an increase in leisure of both men and women ${ }^{28}$.

\footnotetext{
${ }^{27}$ According to the regressions in table 3 labor supply peaks at the age of 32 in the case of men and 39 in the case of women. These are much younger than the ones observed in the West. The young age seems to be a manifestation of a cohort effect, older people being more prone to unemployment.

${ }^{28}$ Table 3 supports also the previous finding that wives' sleep time increased over the period.
} 


\section{F. A Second Look - The Allocation of Time and Employment Status}

The regression results for market time closely resemble those of the labor force participation function. To what extent are the time use patterns of other activities just a reflection of whether the person is employed or not? To answer this question, we regressed the four years mean for each person on his socioeconomic characteristics and the number of years he was employed during the four rounds (table 4). As suspected, employment status is shown to be the main determinant of working hours. The mean hours of market work (including commuting time) is 40.3 hours for employed married men and 36.7 hours for employed married women. Schooling is the only the socio-economic variable that has a significant effect on the working hours of employed men, and only age and urban location affect those of employed women ${ }^{29}$.

Employment status plays a major role determining home time uses, but the number of hours spent by a person on work at home, childcare and leisure is affected also by other socio-economic characteristics. Young children are associated with increased work at home (of their mothers), increased childcare (of both parents), and a reduction of leisure whether the person is employed or not. The amount of time spent on each of the home activities is positively correlated with the amount spent by the spouse. On the other hand, controlling for employment, market work hours of husbands and wives are not correlated, indicating that the correlation observed in table 3 should be traced to the correlation between a person's employment status and the hours of work of his spouse.

How sensitive is work at home to employment status? According to table 4, market employment reduces the mean by 1.7 hours (i.e., by 6.8 weekly hours) in the case of married men, and by 2.8 hours (i.e., by 11.1 weekly hours) in the case of women ${ }^{30}$. Half of the decline in the case of men, and one-quarter in the

\footnotetext{
${ }^{29}$ In the regressions reported in table 4 the line was not forced through the origin (i.e., the intercept was not set to equal zero). The intercept represents, therefore, the sum of the effects of the socio-economic variables at their mean points.

${ }^{30}$ The regression coefficient of employment status in table 4 measures the effect of annual employment on the 4-year mean. To derive the effect on weekly hours the coefficient has to be multiplied by 4 .
} 
case of women, comes at the expense of work on the household's plot or garden. Employment is associated also with a decline in childcare time $(2.4$ hours for men, and more than 9 hours for women), but the main source of the working hours is leisure (28.2 hours in the case of men, and 14.9 for women).

The employment effect in Table 4 mixes the effect of a change in the employment status on the allocation of time with the cross-section differences between those who are regularly employed and those often not-employed. To isolate the first effect a fixed effect regression was estimated (table 5). Those who are prone to change work status work in the market on average fewer hours than the rest of the population. The change in employment status involves a change of 38 hours in the case of men and 33 hours in the case of women $^{31}$. The results relating the other time uses confirm the earlier findings. Only slightly over one-fifth of the hours saved when a man becomes not employed are channeled into work at home and childcare, almost 80 percent going into sleep and leisure. Women, on the other side, divide the additional time almost equally between the two activities ${ }^{32}$.

Testing for symmetry, there is no significant difference between the case where the person joins the ranks of the employed and the case where he leaves employment. In an economy struck by unemployment it is sometimes difficult to tell the unemployed from those out of the labor force. Trying to isolate the effect of unemployment on the allocation of time, the results resemble closely those for the not employed.

Table 6 compares the allocation of time of the employed and not-employed controlling for differences in socio-economic characteristics ${ }^{33}$. The results

\footnotetext{
${ }^{31}$ These changes are significantly lower than the mean market hours of the employed which are 44 and 38 , respectively.

${ }^{32}$ The variables "schooling" and "urban" are omitted from the table because they do not vary over time. Age is omitted because of the inclusion of the year dummies. An additional young child has a significant effect on his parents' time inputs in childcare at the expense of leisure. For unexplained reasons it leads its father to sleep more, and his mother to sleep less.

${ }^{33}$ Table 6 is based on the regression coefficients reported in table 4. Let $\tilde{Y}$ denote the mean weekly hours spent on the activity, and let $\tilde{Y}_{\mathrm{E}}$ and $\tilde{\mathrm{Y}}_{\mathrm{NE}}$ denote the corresponding means for the employed and the not-employed, respectively. Then

$$
\tilde{\mathrm{Y}}_{\mathrm{E}}=\tilde{\mathrm{Y}}+(4-\mathrm{m}) * \mathrm{~b}_{\mathrm{E}} \text {, and } \tilde{\mathrm{Y}}_{\mathrm{NE}}=\tilde{\mathrm{Y}}-\mathrm{m} * \mathrm{~b}_{\mathrm{E}}
$$
}


confirm the fixed-effect regression findings: whereas in the case of married women 55 percent of the difference in market hours is taken up by work at home and childcare, in the case of married men 75 percent is taken up by leisure and sleep. Hence, an increase in the not employed will be associated with a substantial increase in the output of the non-market sector only if the newly not employed come from the ranks of the married women.

Table 6 is revealing also in another sense: though the increase in non-market work of the not-employed men is quite modest in absolute terms, it can only be called gigantic in relative terms. Given the low contribution of employed married men, the time spent by the not-employed in work at home is almost twice that of the employed, and the amount spent in leisure is almost 50 percent higher. The comparable figures for not-employed married women are onethird. If one is to believe that these changes are voluntary reactions to wage changes, than the wage change has to be quite considerable or the sensitivity of work at home and leisure to wage changes has to be, at least in the case of men, quite $\operatorname{large} \mathrm{e}^{34}$.

Lucas and Rapping (1969) regard the fluctuations in market hours as voluntary. In their words, "measured unemployment is then viewed as consisting of persons who regard the wage rates at which they could currently be employed as temporarily low and who therefore choose to wait or search for improved conditions rather than to invest in moving or occupational change". Can the panel data shed any new light on the "intertemporal substitution of leisure hypothesis"? The Lucas-Rapping conjecture can be given two interpretations: According to the first, relying on perfect foresight (or rational expectations), workers who are prone to unemployment (i.e., periods of "unsatisfactory" wages) will work more hours when employment opportunities abound (when the wage is sufficiently high). According to the second interpretation,

\footnotetext{
Where $m$ denotes the average number of periods (out of 4 ) where the person is employed, and $b_{E}$ denotes the employment effect (as measured by the corresponding regression coefficient). The value of $\mathrm{m}$ is 3.23 for men and 2.7 for women.

${ }^{34}$ Rupert et. al. (1995) adopt as parameters of the home production elasticity $\eta$ the values 0.1 for men and 0.65 for women. Their range of estimates for the elasticity of substitution between market and home goods ranges from 1.57 to 4 . A very crude calculation shows that only a wage decline of $30-50$ percent can yield the changes observed in table 6 .
} 
"unsatisfactory" wages, leading to the choice of unemployment, are random shocks, to which the person reacts by working harder when he resumes employment.

To test the first interpretation I compared the average market hours of married men and women who differ in the length of their employment spans (i.e., 4 rounds, 3 rounds, etc.). A similar comparison was conducted for the average leisure hours (including sleep). At first hand the results presented in table 7 look revealing ${ }^{35}$. Married men who worked only for one period worked in that period 6 percent more than the annual average of men who worked throughout all the 4 periods. These men tended also to work more at home, and as a result had 8 percent less time (compared with the continuous workers) for leisure and sleep ${ }^{36}$. Lucas and Rapping would have found the patterns of time use of married women more disturbing. Married women tend to work less the looser their attachment to the labor market. Thus, women who reported only one period of employment work during that period 14 percent less than the continuous workers, having 6 percent more hours to spend on leisure and sleep. To test whether the results are statistically significant the regressions of table 3 were re-estimated, where the sample is confined to the employed, and 3 dummy variables denote the number of periods the person was employed (table $8)^{37}$. The regressions show that while the results reported for women are statistically significant, those for men are not.

To test the second interpretation, namely that persons tend to compensate in terms of increased work effort for unforeseen periods of unemployment, I confined the sample to those reporting having worked in the first and last round of the survey, and I examined to what extent does the employment record in the

\footnotetext{
${ }^{35}$ The means are computed only for the periods during which the person was employed. The comparison in table 7 is based on a balanced sample, which explains the decline in the sample size compared to tables 2-6.

${ }^{36}$ Note that though the Lucas-Rapping hypothesis is called "the intertemporal substitution of leisure" hypothesis", it relates to non-market time and not specifically to leisure. It can be argued that the differences in the means of the market hours reflect differences in industrial composition, and that industries that are more exposed to cyclical shocks are characterized by longer work hours, but this argument does not stand in contradiction to the Lucas-Repping hypothesis

${ }^{37} \mathrm{Empl} \mathrm{n}$ denotes that the person was employed in $\mathrm{n}$ out of the 4 years. The sample is the balanced panel.
} 
interim periods affect the change in time-use patterns over these 5 years. As table 9 testifies, we could not find a trace of an effect - the changes in market work and leisure hours (the decline and the increase, respectively) are completely independent of whether the person was employed in 1995-1996 or not. It can be argued that the our sample is too small, and that the number of persons not employed in the mid-years was too scanty (10 percent of men and 7 percent of women) to detect these effects, but the sample seems to be large enough to detect the effect of the change in the number and age composition of children on their parents' leisure. The verdict one can draw from the Russian experience on the validity of the intertemporal substitution of leisure hypothesis is, therefore, negative.

\section{G. Some Preliminary Conclusions}

The failure of the Lucas-Rapping "intertemporal substitution of leisure" hypothesis to explain the large fluctuations over the business cycle in output and employment associated with only small movements in the real wage led macroeconomists to search for an explanation in home production ${ }^{38}$. The explanation in terms of the intertemporal margin was replaced by an explanation in terms of the intra-temporal substitution between work in the market and work at home ${ }^{39}$. A key parameter in the new explanation is the supposedly high elasticity of substitution between market and home goods. Previous microeconomic studies of home production assumed that this elasticity is infinite. The new generation of macro studies rejects this extreme assumption in favor of a more general model that allows for both a finite elasticity of substitution and diminishing returns in home production. In the absence of micro estimates of the relevant parameters, the new studies employ arbitrary values in their calibration exercise in an attempt to mimic the

\footnotetext{
${ }^{38}$ An analysis of this failure is contained in Blanchard and Fischer (1989).

39 Note that the low estimates of the elasticity of substitution between market and non- market time reflect not merely the low intertemporal substitution between market work and leisure, but also a low intertemporal substitution between market work and work at home.
} 
fluctuations in the market labor input over the business cycle. Since time series on the changes in leisure and work at home are unavailable no attempt is made to mimic the fluctuations in the allocation of time at home.

The arbitrary nature of the parameters and the scanty information on the changes in the economic activity at home has been a source of uneasiness to many macroeconomists ${ }^{40}$. This paper explores to what extent insights gained through micro studies can help macroeconomists in their plight.

Expanding on the Pollak and Wachter's criticism of Becker's home production model I argue that there is no way of resolving the first problem- that is, there is no way of estimating separately the elasticity of substitution between market and home goods and the elasticity of home production with respect to work at home. The failure of the new studies to isolate these parameters is, therefore, not accidental, since the model does not satisfy the fundamental econometric identification rules. Similarly, it is shown, that when the elasticity of substitution is estimated in a restricted model where the elasticity of home production with respect to work at home is set arbitrarily, the estimate is heavily dependent on the arbitrarily chosen values.

In the absence of data in the Western economies on the cyclical changes in home production, this paper explores the experience of the Russian economy in the second half of the 90s. Russia went in the last 15 years through a painful process of transition from a centrally planned economy to a market oriented one. The process was accompanied by a sharp decline in output, a decline of real wages and increased unemployment. A panel of time budgets collected during the trough of the depression allows us for the first time to follow the adjustments households make in their home activities in the face of declining employment opportunities.

In Russia, as in Western economies, the home production industry is dominated by women. Married women contribute almost 80 percent of the hours devoted to work at home, and over two-thirds of the hours spent on childcare. There is a

\footnotetext{
${ }^{40}$ The feeling of uneasiness has not been confined to macroeconomists. In response to increasing demand, several government statistical offices (among them, the U.S. and Israel) started to collect systematic data on the time spent on home activities.
} 
significant difference in the time inputs of those women who are fully "employed" in this sector and "part-timers"- women who split their work time between the market and home. "Full-timers" spend on work at home one-third more time than is spent by the "part-timers", and they spend on childcare 50 percent more than is spent by members of the other group. Consequently, though full- time housewives constitute only about one-sixth of our sample they contribute approximately one-third of the hours spent on work at home and childcare.

At the beginning of the sample period working men devoted to work at home only one-third the time spent by working women, and this ratio has been shrinking over time. The not-employed work at home twice as much as the employed, but still men's contribution to the home work effort is limited. Russian married men's record is slightly better when it comes to time inputs in childcare, where they devote almost one-third of the household time.

The panel fixed effect regressions confirm the impressions one gets from the cross-section data. There exists a significant difference in the way members of the different genders react to loss of employment (or alternatively, exit from unemployment). The difference is manifested in the way they reallocate the time released from market labor: whereas men divert three-quarters of it to leisure, only one quarter going to work at home and child care, women split the released time almost evenly between these two time uses. Not surprising, it is the change in the employment status of women that determines the fluctuation in home output over the business cycle.

Life under the Soviet regime was characterized by heavy work loads and little free time. The burden of long market hours (and high labor force participation rates) was aggravated by the inefficiency of the home sector reflected in long hours spent on work at home. The prime victims of the inefficiency were Russian women, a majority of whom had to cope with two full-time work loads- in the market and at home. Things seemed to ease towards the end of the Soviet era, but the increase in free time was reported to have dwindled almost to a stop during the early years of the transition period. The halt was blamed on 
the increased hours spent in home production (and specifically, gardening) in response to the deterioration in market earnings. To what extent are these conclusions supported by our findings?

The answer to this question told by Table 10 is definitely negative. The substitution from market goods to home goods seemed to be too weak to block the long term secular trend. The drive for more free time, that may have halted in the early years of the transition period, has resumed, and even accelerated, in the second half of the $90 \mathrm{~s}$.

Hours of market work of married men declined by a fifth, and those of married women by almost a tenth. Though Russians tried to compensate for dwindling income by producing some of their food in their gardens, the increased time inputs in gardening were overshadowed by the increased efficiency of the home sector reflected in the sharp decline in the time it takes to carry out the other home tasks. The increase in efficiency was reinforced by the decline in fertility. The latter contributed to the shorter home work hours, but is manifested primarily in the smaller time inputs going into child care. According to the our sample, Russian couples spent in 1998 one-fifth less time on work at home and childcare then they spent in 1994. The time savings at home exceeded, both in absolute and relative terms, the time savings in work in the market. The decline in working hours in the market and at home led to a sharp increase in free time. Some of it was spent in more sleep, but most of it was devoted to other activities. A couple's "leisure time" increased by one-fifth, and husband and wives shared almost equally in this boon.

It is of interest to separate the increase in free time that is due to the decline in employment rates, which may be of a temporary nature, from the long term trend. To isolate the impact of the change in employment rates I calculated the mean allocation of time of married men and women assuming that the time-use patterns of the employed and not employed have not changed over the period ${ }^{41}$.

\footnotetext{
${ }^{41}$ The mean hours reported in table 10 are based on the standardized 4-year means for the employed and not-employed reported in table 6 , where the weights assigned to the employed and not employed are determined by the labor fore participation rates which decline over time. (The relevant LFPR are reported at the bottom of the table).
} 
The results reported in table 10 indicate that though the cyclical change in employment rates was crucial in the decline of market hours, it played only a small role in the increased free time.

The changes in participation resulted in a decline of almost 14 percent in the supply of labor of men and a decline of 12 percent in the labor supply of women. This decline explains two-thirds of the total decline in the labor supply of men and the whole decline in that of women ${ }^{42}$. Had it not been for the secular decline in work at home, married men would have increased their involvement in home production (work at home and child care) by 8 percent, and their wives by about 4, resulting in a 5 percent increase for an average couple $^{43}$. Similarly, the decline in employment contributed to a to a 5 percent increase in "leisure". This increase accounts, however, only for one quarter of the actual increase in free time over the period.

The time-use panel allows an examination of the effect of unemployment spells on the person's patterns of work and leisure when he is employed. Based on the Lucas-Rapping hypothesis, two tests are proposed. The first one, relying on rational expectations, examines whether persons exposed to higher probabilities of unemployment work harder when they are employed. The second test regards unemployment as a random shock to which people react by working harder once they are reemployed. The results of both tests are not supportive of the Lucas-Rapping hypothesis: men's work effort seems to be unaffected by the length of their employment spell, while women who are more attached to the labor market- work more. The second test is rejected outrightmarket hours are not affected by previous unemployment spells.

What are the lessons for the new macroeconomics of home production that we take with us from the Russian experience? Perhaps the main lesson concerns the complexity of the processes taking place in the market and at home during the business cycle. There are significant differences in the reaction of men and women, of the employed and the not employed to the changing market

\footnotetext{
${ }^{42}$ These results are consistent with Lilien and Hall's (1986) conclusion that in the US in the post-war era employment changes accounted for over three-quarters of the cyclical change in total hours worked. ${ }^{43}$ The couple's gardening activity increased by over 9 percent.
} 
prospects in a period of recession. It is hard to see how this complexity can be captured by a model of a representative consumer reacting to fluctuations in the mean wage rate. To judge by the Russian experience, the one sector model used in the calibrations should be replaced by a two-sector model, where intertemporal substitution of leisure drives the "masculine" sector, and the intratemporal substitution of market and home goods applies to the "feminine" sector. Given the ever increasing share of the "feminine" sector in the over-all economic activity of the Western economies, trying to calibrate a "unified" aggregate model, runs the risk of composition biases. The failure of the traditional RBC models to track the cyclical fluctuations in market hours has been traced to the use of a low estimate of the intertemporal elasticity of substitution of leisure, an estimate based on the labor supply of men (Becker and Ghez 1975; McCurdy 1981; Browning, Deaton and Irish 1985). The new RBC models of household production run a similar risk, basing their calibration exercise on the high intra-temporal substitution between home and market work observed in studies of the labor force participation of married women.

Even more problematic seems the reliance on the mean wage as the sole motivating force propelling the system. A recession affects different people in the labor force differently. A recession is a period of increasing diversity- some people are hardly affected and others have to go through major changes in their lifestyle. Focusing on the central moment of the distribution one implicitly gives up telling this story of diversity. Specifically, changes in the mean may not be able to explain why some people are induced to move from an interior solution to a corner solution: from being "part timers" in the home industry to becoming "full timers". The distinction between the internal margin and the external margin is in particular important in the context of household activities. The variation in hours spent in work at home or in leisure by the employed is relatively small compared with the differences in the time schedules between the employed and not employed. To study the variation in home production 
over the business cycle one has to study these differences rather than the reaction of the allocation of time of the employed to changes in their wages ${ }^{44}$. An average Russian couple spends about one-sixth of its time in market work. To most economists market work is like a tip of an iceberg, most of which is hidden. Trying to explain cyclical changes in market hours in terms of changes taking place in the hidden part may look at first as an elegant way to overcome the shortcomings of previous explanations. The more, however, we learn about the changes taking place in the home sector during the business cycle we may find that the new macro theory, instead of simplifying the story - complicates it. It will require the joint skills of micro and macro economists to tell this richer version of the story of cyclical variation in market and home activity.

\section{References:}

\footnotetext{
${ }^{44}$ Not less disturbing is the truncation problem arising from the fact that the wage of those who had exited employment does not show up in the changes in the mean wage. If workers who get lower wages are more prone to drop out of employment than the change in the wage will be understated.
} 
Aguiar Mark; Hurst Eric. "Measuring Trends in Leisure: Evidence from Five Decades of Time Use Surveys", NBER Working Paper 12082 (March 2006).

Becker, Gary S. "A Theory of the Allocation of Time," E.J. 75 (1965): 493-517

Becker, Gary S. "Family Economics and Macro Behavior." A.E.R. 78(1)

(March 1988):1-13.

Becker Gary S; Ghez Gilbert. The Allocation of Time and Goods Over the Life Cycle. NBER, Columbia University Press, 1975: 83-132.

Benhabib, Jess; Rogerson, Richard; Wright, Randall. "Homework in Macroeconomics: Household Production and Aggregate Fluctuations." J.P.E. 99(6) (Dec. 1991): 1166-87

Biddle, Jeff ; Hamermesh, Daniel. "Sleep and the Allocation of Time," J.P.E., 98 (Oct. 1990): 922-43.

Blanchard, Olivier; Fischer Stanley. Lectures on Macroeconomics, MIT Press 1989.

Browning, Martin; Deaton Angus; Irish M. "A Profitable Approach to Labor Supply and Commodity Demand over the Life-Cycle," Econometrica 53(1985),: 503543.

Campbell, John Y; Ludvigson, Sydney. "Elasticities of Substitution in Real Business Cycle Models with Home Production.” Journal of Money, Credit, and Banking. 33(4) (Nov. 2001): 847-75

Cooley Thomas F.; Prescott Edward C. " Economic Growth and Business Cycles", ," in Thomas Cooley, ed., Frontiers of Business Cycle Research. Princeton, NJ: Princeton University Press, 1995.

Earle John.S; Sabirianova Klara ."Coping with Crisis: Russian Labor Markets in Transition", Mimeo (April 2001)

Einarsson, Tor; Marquis, Milton H. "Home Production with Endogenous Growth." Journal of Monetary Economics. 39(3) (Aug. 1997): 551-69 
Gollin, Douglas; Parente, Stephen L; Rogerson, Richard. "Farm Work, Home Work and International Productivity Differences." Review of Economic Dynamics. 7(4) (Oct. 2004): 827-50

Gomme, Paul; Kydland, Finn E; Rupert, Peter. "Home Production Meets Time to Build." J.P.E. 109(5) (Oct 2001): 1115-31

Graham, J.W., Green, C.A. "Estimating the Parameters of the Household Production Function with Joint Products". ReStat 66 (1984):277-282.

Greenwood, Jeremy ; Hercowitz Zvi."’The Allocation of Capital and Time over the Business Cycle.' J.P.E. 99(6) (Dec. 1991 ) : 1188-1214.

Greenwood, Jeremy; Rogerson, Richard; Wright, Randall. "Household Production in Real Business Cycle Theory," in Thomas Cooley, ed., Frontiers of Business Cycle Research. Princeton, NJ: Princeton University Press, 1995.

Gronau, Reuben. "Leisure, Home Production, and Work-The Theory of the Allocation of Time Revisited."J.P.E. 85(6) (Dec. 1977): 1099-1123

Gronau, Reuben; Hamermesh, Daniel S. "The Demand for Variety: A Household Production Perspective.” NBER Working Paper no. 8509, 2001

Ingram, Beth F; Kocherlakota, Narayana R; Savin, N. E. "Using Theory for Measurement: An Analysis of the Cyclical Behavior of Home Production." Journal of Monetary Economics. 40(3) (Dec. 1997): 435-56

Kerkhofs, Marcel; Kooreman, Peter." Identification and Estimation of a Class of Household Production Models." Journal of Applied Econometrics. 18(3)( May-June 2003): 337-69

.Kim Byung Yeon. "Informal Economy Activities of Soviet Households: Size and Dynamics", Jourmnal of Comparative Economics 31(3) (September 2003: 523-551.

Kolev Alexandre. "Labor Supply in the Informal Economy in Russia during Transition" CEPR Discussion Paper 2024(1998).

Kuznets, Simon.. National Income and its Composition. Vol. II. New York: NBER 1944. 
Lilien David M.; Hall Robert E. "Cyclical Fluctuations in the Labor Market" in Ashenfelter, Orley, and Layard, Richard, (eds). Handbook of labor economics. Vol. 2. New York: North-Holland 1986:1002-1035.

Lucas, Robert E. Jr; Rapping Leonard A. "Real Wages Employment and Inflation”. J.P.E. 77 (September/October 1969):721-754

Marquis, Milton H. "Inflation taxes, financial intermediation, and home production” Federal Reserve Bank of San Francisco, Working Papers in Applied Economic Theory: 2001-04 (2001)

McGrattan, Ellen R; Rogerson, Richard; Wright, Randall. “An Equilibrium Model of the Business Cycle with Household Production and Fiscal Policy." I.E.R. 38(2) (May 1997): 267-90

MaCurdy, Thomas E., "An Empirical Model of Labor Supply in Life Cycle Setting," JPE_89(6) (1981): 1058-1085.

Parente, Stephen L; Rogerson, Richard; Wright, Randall. "Homework in Development Economics: Household Production and the Wealth of Nations.” J.P.E. 108(4) (Aug. 2000): 680-87

Perli, Roberto. "Indeterminacy, Home Production, and the Business Cycle: A Calibrated Analysis." Journal of Monetary Economics. 41(1) (Feb. 1998): $105-25$

Pollak, Robert; Wachter, Michael. "The Relevance of the Household Production Function and Its Implications for the Allocation of Time," J.P.E. 83 (Apr. 1975): 255-78.

Robinson, John P; Godbey Geoffrey. Time for Life: The Surprising Ways Americans Use Their Time, $2^{\text {nd }}$ ed. University Park, PA: Pennsylvania State University Press, 1999.

Rupert, Peter; Rogerson, Richard; Wright, Randall.“Estimating Substitution Elasticities in Household Production Models.'Economic Theory. 6(1) (June 1995): 179-93

The World Bank. The Russian Labor Market: moving from Crisis to Recovery,2003. 
Table 1. The Allocation of Time of Russian People 2004-2008

(mean hours /week)

\begin{tabular}{|c|c|c|c|c|c|c|c|c|c|c|c|c|}
\hline \multirow{2}{*}{$\begin{array}{l}\text { Round: } \\
\text { Sample size }\end{array}$} & \multicolumn{3}{|c|}{$\mathbf{V}$} & \multicolumn{3}{|c|}{ VI } & \multicolumn{3}{|c|}{ VII } & \multicolumn{3}{|c|}{ VIII } \\
\hline & & 7520 & & & 7041 & & & 6947 & & & 7375 & \\
\hline Activity & $\begin{array}{l}\text { Mean } \\
\text { Hours }\end{array}$ & Incidence & $\begin{array}{l}\text { Mean } \\
\text { Hours }\end{array}$ & $\begin{array}{l}\text { Mean } \\
\text { Hours }\end{array}$ & Incidence & $\begin{array}{l}\text { Mean } \\
\text { Hours }\end{array}$ & $\begin{array}{l}\text { Mean } \\
\text { Hours }\end{array}$ & Incidence & $\begin{array}{l}\text { Mean } \\
\text { Hours }\end{array}$ & $\begin{array}{l}\text { Mean } \\
\text { Hours }\end{array}$ & Incidence & $\begin{array}{l}\text { Mean } \\
\text { Hours }\end{array}$ \\
\hline Total market work & 21.94 & $\underline{0.48}$ & 45.97 & 22.64 & $\underline{0.48}$ & 46.80 & $\underline{21.26}$ & $\underline{0.46}$ & $\underline{46.26}$ & $\underline{19.18}$ & $\underline{0.43}$ & $\underline{44.61}$ \\
\hline Market work & 19.54 & 0.48 & 40.94 & 20.28 & 0.48 & 41.93 & 19.13 & 0.46 & 41.63 & 17.24 & 0.43 & 40.11 \\
\hline Commuting & 2.40 & 0.48 & 5.03 & 2.36 & 0.48 & 4.87 & 2.13 & 0.46 & 4.64 & 1.93 & 0.43 & 4.50 \\
\hline Work at home & 20.44 & - & - & 19.70 & - & - & $\underline{18.93}$ & - & - & $\underline{16.34}$ & - & - \\
\hline Gardening & 2.12 & 0.13 & 15.92 & 3.85 & 0.27 & 14.22 & 4.00 & 0.29 & 13.72 & 2.19 & 0.16 & 13.51 \\
\hline Food purchase & 3.28 & 0.56 & 5.87 & 2.75 & 0.55 & 4.97 & 2.34 & 0.55 & 4.22 & 2.25 & 0.56 & 4.03 \\
\hline Cooking & 8.48 & 0.71 & 11.89 & 7.66 & 0.68 & 11.20 & 7.53 & 0.69 & 10.87 & 7.35 & 0.71 & 10.33 \\
\hline Cleaning & 4.24 & 0.68 & 6.25 & 3.41 & 0.61 & 5.62 & 3.16 & 0.62 & 5.13 & 2.88 & 0.63 & 4.56 \\
\hline Laundry & 2.32 & 0.49 & 4.74 & 2.03 & 0.47 & 4.29 & 1.90 & 0.49 & 3.91 & 1.68 & 0.48 & 3.49 \\
\hline Chid care & $\underline{7.35}$ & - & - & 6.54 & - & - & $\underline{6.65}$ & $\ldots$ & - & $\underline{6.61}$ & - & - \\
\hline$\overline{\text { Own child }}$ ren & $\overline{6.07}$ & 0.34 & 18.04 & $\overline{5.49}$ & 0.32 & 17.09 & $\overline{5.80}$ & 0.33 & 17.48 & $\overline{5.65}$ & 0.31 & 18.00 \\
\hline Other children & 1.28 & 0.09 & 13.80 & 1.05 & 0.08 & 13.39 & 0.85 & 0.07 & 11.83 & 0.95 & 0.08 & 12.02 \\
\hline $\begin{array}{l}\text { Help parents } \\
\underline{\text { (others) }}\end{array}$ & $\underline{0.98}$ & $\underline{0.05}$ & $\underline{19.05}$ & $\underline{0.69}$ & $\underline{0.04}$ & $\underline{18.22}$ & $\underline{0.86}$ & $\underline{0.04}$ & $\underline{19.05}$ & $\underline{0.75}$ & $\underline{0.05}$ & $\underline{16.15}$ \\
\hline$\underline{\text { Sleep }}$ & $\underline{52.20}$ & $\underline{1.00}$ & $\underline{52.20}$ & $\underline{52.74}$ & $\underline{1.00}$ & $\underline{52.74}$ & 52.87 & $\underline{1.00}$ & $\underline{52.87}$ & $\underline{53.41}$ & $\underline{1.00}$ & $\underline{53.41}$ \\
\hline$\underline{\text { Residual (Leisure) }}$ & 65.08 & & & 65.69 & & & 67.43 & & & 71.71 & & \\
\hline
\end{tabular}

Source : RLMS Rounds IV-VIII 
Table 2. The Allocation of Time of Russian Married Men and Women 1994-1998

(Mean hours/ week)

\begin{tabular}{|c|c|c|c|c|c|c|c|c|}
\hline & \multicolumn{4}{|c|}{ Married Men } & \multicolumn{4}{|c|}{ Married Women } \\
\hline Activity & 1994 & 1995 & 1996 & 1998 & 1994 & 1995 & 1996 & 1998 \\
\hline Total market work & $\underline{37.6}$ & $\underline{38.1}$ & $\underline{34.8}$ & $\underline{30.0}$ & $\underline{26.4}$ & $\underline{26.8}$ & $\underline{25.9}$ & $\underline{24.1}$ \\
\hline Market work & 33.6 & 34.3 & 31.7 & 27.0 & 23.6 & 24.2 & 23.5 & 21.7 \\
\hline Commuting & 4.0 & 3.8 & 3.1 & 3.0 & 2.8 & 2.6 & 2.4 & 2.4 \\
\hline Work at home & $\underline{10.5}$ & $\underline{9.1}$ & $\underline{8.7}$ & 7.2 & $\underline{34.5}$ & $\underline{33.8}$ & $\underline{31.0}$ & $\underline{28.2}$ \\
\hline Gardening & 3.1 & 5.5 & 5.3 & 3.5 & 2.1 & 4.2 & 4.1 & 2.3 \\
\hline Food purchase & 1.7 & 1.1 & 0.9 & 1.0 & 4.7 & 3.9 & 3.4 & 3.3 \\
\hline Cooking & 2.3 & 1.5 & 1.6 & 1.8 & 16.5 & 15.4 & 14.4 & 14.1 \\
\hline Cleaning house & 3.0 & 0.8 & 0.7 & 0.8 & 6.4 & 6.1 & 5.3 & 5.1 \\
\hline Laundry & 0.3 & 0.2 & 0.2 & 0.2 & 4.8 & 4.2 & 3.8 & 3.4 \\
\hline$\underline{\text { Child care }}$ & $\underline{5.8}$ & $\underline{4.9}$ & $\underline{5.2}$ & $\underline{4.6}$ & $\underline{12.5}$ & $\underline{11.2}$ & $\underline{11.4}$ & $\underline{9.9}$ \\
\hline Help parents (others) & $\underline{0.5}$ & $\underline{0.4}$ & $\underline{0.4}$ & $\underline{0.4}$ & $\underline{1.1}$ & $\underline{0.8}$ & $\underline{0.8}$ & $\underline{1.0}$ \\
\hline$\underline{\text { Sleep }}$ & $\underline{51.3}$ & $\underline{51.6}$ & $\underline{51.5}$ & $\underline{52.2}$ & $\underline{50.5}$ & $\underline{50.9}$ & $\underline{51.2}$ & $\underline{51.8}$ \\
\hline$\underline{\text { Residual (Leisure) }}$ & $\underline{62.3}$ & $\underline{63.9}$ & $\underline{67.4}$ & $\underline{73.5}$ & 43.0 & $\underline{44.4}$ & 47.6 & $\underline{53.0}$ \\
\hline $\begin{array}{l}\text { Labor force } \\
\text { participation }(\%)\end{array}$ & 86.4 & 85.3 & 79.1 & 73.6 & 75.3 & 73.0 & 71.0 & 65.8 \\
\hline no. of observations & 994 & 932 & 980 & 1077 & 994 & 932 & 980 & 1077 \\
\hline
\end{tabular}

Source : RLMS Rounds IV-VIII 
Table 3a. The Determinants of the Allocation of Time of Russian Married Men 1994-1998

4- year cross-section regressions

\begin{tabular}{|c|c|c|c|c|c|c|c|c|c|c|}
\hline & \multicolumn{2}{|c|}{ Market work } & \multicolumn{2}{|c|}{ Work at home } & \multicolumn{2}{|c|}{$\begin{array}{l}\text { Childcare/ } \\
\text { Parent care }\end{array}$} & \multicolumn{2}{|c|}{ Sleep } & \multicolumn{2}{|c|}{ "Leisure" } \\
\hline & $\mathrm{b}$ & $\mathrm{t}$ & $\mathrm{b}$ & $\mathrm{t}$ & B & $\mathrm{t}$ & $\mathrm{b}$ & $\mathrm{t}$ & $\mathrm{b}$ & $\mathrm{t}$ \\
\hline Schooling & 0.331 & 2.16 & 0.210 & 2.95 & -0.069 & -1.31 & -0.220 & -4.40 & -0.208 & -1.34 \\
\hline Age & 1.012 & 2.79 & -0.375 & -2.27 & -0.390 & -3.18 & 0.074 & 0.64 & 0.126 & 0.35 \\
\hline $\operatorname{Age}^{\wedge} 2$ & -0.016 & -3.68 & 0.006 & 2.92 & 0.004 & 2.53 & -0.001 & -0.70 & 0.002 & 0.49 \\
\hline no. young cld & -0.203 & -0.28 & -0.912 & -2.70 & 2.390 & 9.17 & 0.074 & 0.31 & -1.567 & -2.12 \\
\hline no. old cld & -0.197 & -0.38 & -0.060 & -0.25 & 0.785 & 4.44 & -0.122 & -0.73 & -0.351 & -0.67 \\
\hline Urban & 1.578 & 1.84 & -3.472 & -8.52 & 0.603 & 2.06 & -0.234 & -0.84 & 1.245 & 1.43 \\
\hline Spouse hours & 0.099 & 5.41 & 0.093 & 8.08 & 0.190 & 20.21 & 0.231 & 13.87 & 0.213 & 13.36 \\
\hline Year 1995 & 0.634 & 0.56 & -1.289 & -2.44 & -0.582 & -1.50 & 0.209 & 0.57 & 0.937 & 0.81 \\
\hline Year 1996 & -2.117 & -1.89 & -1.610 & -3.07 & -0.293 & -0.77 & 0.059 & 0.16 & 3.445 & 3.01 \\
\hline Year 1998 & -6.618 & -6.02 & -3.034 & -5.86 & -0.320 & -0.85 & 0.722 & 2.01 & 8.107 & 7.19 \\
\hline Constant & 16.828 & 2.25 & 12.816 & 3.68 & 12.340 & 4.77 & 40.945 & 15.51 & 46.516 & 6.07 \\
\hline $\operatorname{adj} \mathrm{R} \mathrm{sq}$ & 0.053 & & 0.063 & & 0.214 & & 0.053 & & 0.102 & \\
\hline Mean weekly hours & 34.962 & & 8.853 & & 5.561 & & 51.655 & & 66.969 & \\
\hline No. of observations & 3932 & & 3932 & & 3932 & & 3932 & & 3932 & \\
\hline
\end{tabular}


Table 3b. The Determinants of the Allocation of Time of Russian Married Women 1994-1998

\section{4- year cross-section regressions}

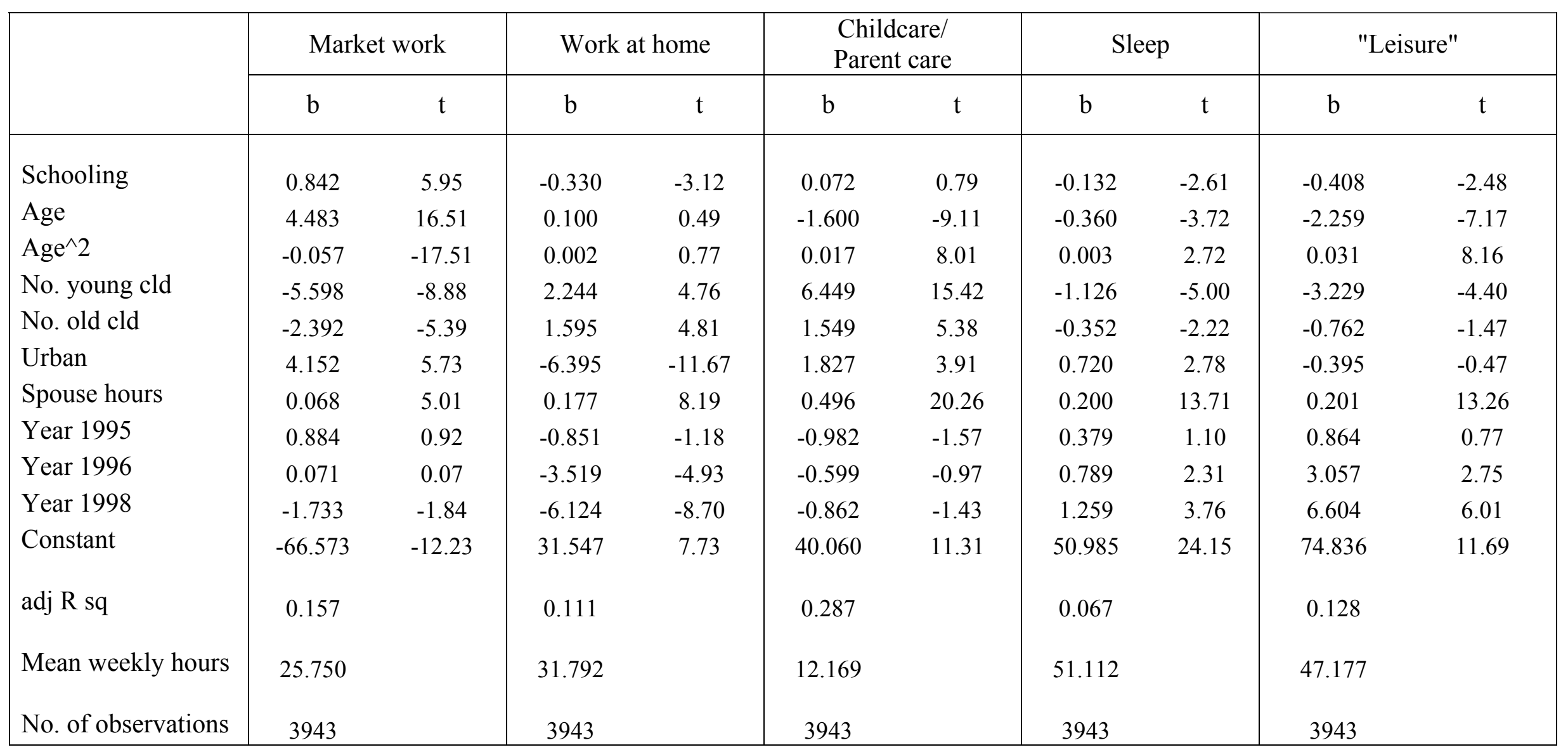


Table 4a. The Effect of Employment Status on the Allocation of Time of Russian Married Men 1994-1998 Regression of 4-year means

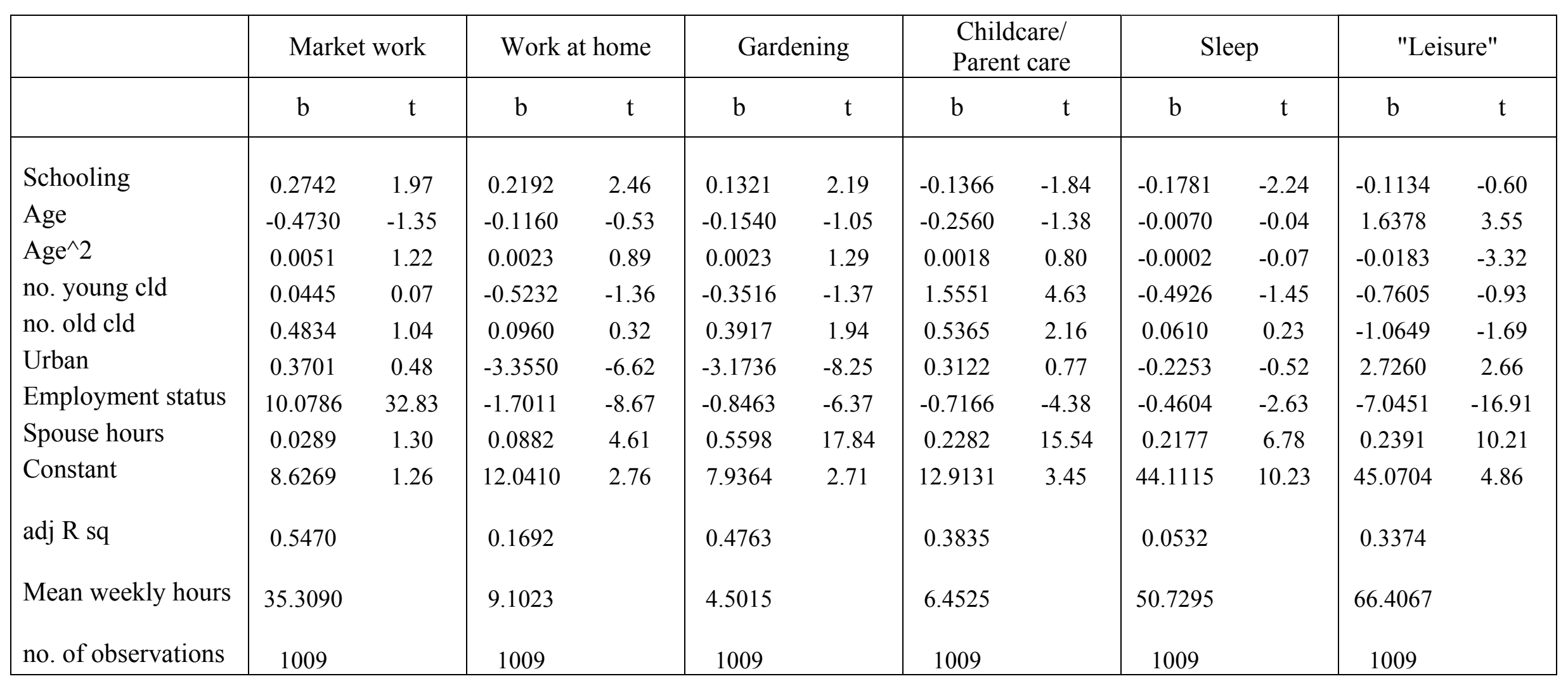


Table 4b. The Effect of Employment Status on the Allocation of Time of Russian Married Women 1994-1998 Regression of 4-year means

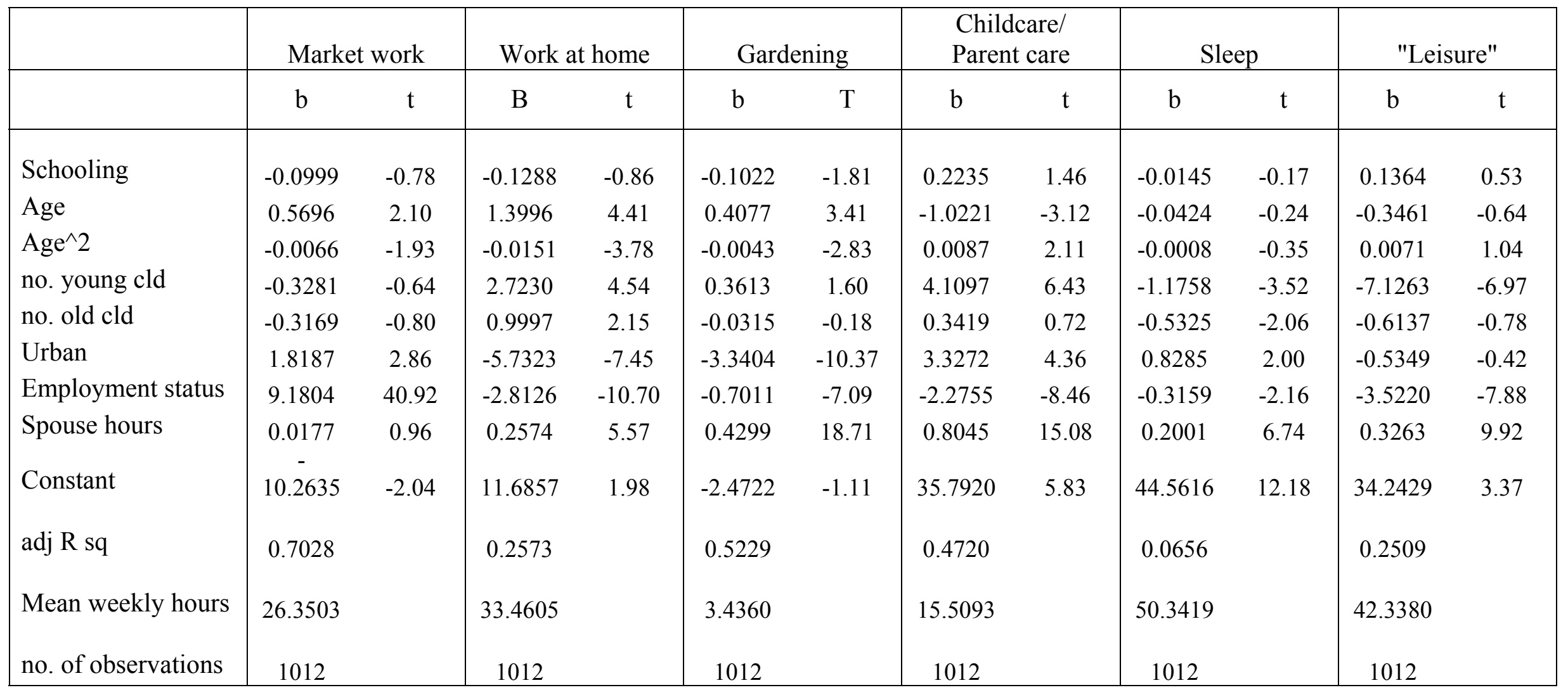

Source: wrknow means 
Table 5a. The Effect of Employment Status on the Allocation of Time of Russian Married Men 1994-1998

Fixed effect regressions

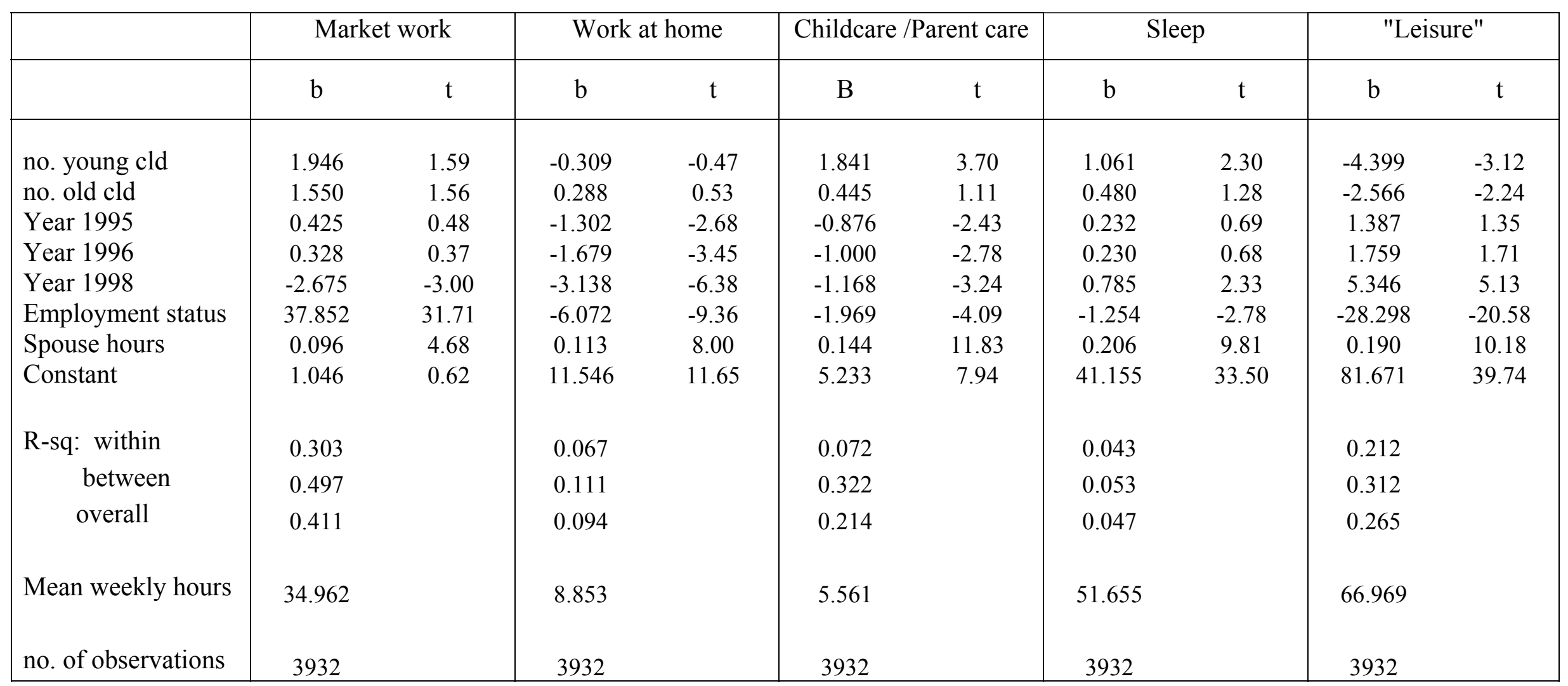


Table 5b. The Effect of Employment Status on the Allocation of Time of Russian Married Women 1994-1998 Fixed effect regressions

\begin{tabular}{|c|c|c|c|c|c|c|c|c|c|c|}
\hline & \multicolumn{2}{|c|}{ Market work } & \multicolumn{2}{|c|}{ Work at home } & \multicolumn{2}{|c|}{ Childcare /Parent care } & \multicolumn{2}{|c|}{ Sleep } & \multicolumn{2}{|c|}{ "Leisure" } \\
\hline & $\mathrm{b}$ & $\mathrm{t}$ & $\mathrm{b}$ & $\mathrm{t}$ & $\mathrm{B}$ & $\mathrm{t}$ & $\mathrm{b}$ & $\mathrm{t}$ & $\mathrm{b}$ & $\mathrm{t}$ \\
\hline no. young cld & -0.113 & -0.12 & -0.669 & -0.76 & 4.153 & 5.52 & -0.724 & -1.75 & -2.851 & -2.06 \\
\hline no. old cld & 0.458 & 0.59 & 0.577 & 0.80 & 1.883 & 3.06 & -0.114 & -0.34 & -2.766 & -2.43 \\
\hline Year 1995 & 1.331 & 1.93 & -0.904 & -1.40 & -1.622 & -2.95 & 0.173 & 0.57 & 1.241 & 1.22 \\
\hline Year 1996 & 0.560 & 0.82 & -3.261 & -5.09 & -1.525 & -2.80 & 0.477 & 1.59 & 3.726 & 3.69 \\
\hline Year 1998 & 0.394 & 0.57 & -6.362 & -9.96 & -2.520 & -4.66 & 0.867 & 2.90 & 7.035 & 6.93 \\
\hline Employment status & 32.763 & 36.16 & -8.567 & -10.13 & -5.811 & -8.07 & -1.743 & -4.37 & -16.297 & -12.24 \\
\hline Spouse hours & 0.055 & 4.36 & 0.203 & 8.12 & 0.345 & 12.08 & 0.164 & 9.62 & 0.171 & 9.86 \\
\hline Constant & 0.914 & 0.74 & 38.261 & 34.67 & 12.797 & 13.81 & 43.720 & 43.08 & 46.644 & 22.57 \\
\hline R-sq: within & 0.3376 & & 0.0969 & & 0.0988 & & 0.0495 & & 0.1312 & \\
\hline between & 0.6597 & & 0.1695 & & 0.3882 & & 0.0727 & & 0.1995 & \\
\hline overall & 0.5441 & & 0.1342 & & 0.2747 & & 0.0609 & & 0.1783 & \\
\hline Mean weekly hours & 25.75037 & & 31.79177 & & 12.16866 & & 51.11235 & & 47.17684 & \\
\hline no. of observations & 3943 & & 3943 & & 3943 & & 3943 & & 3943 & \\
\hline
\end{tabular}


Table 6. The Allocation of Time of the Employed and Not- Employed 1994-1998 4-year means

\begin{tabular}{|c|c|c|c|c|c|c|c|c|c|c|}
\hline & \multicolumn{5}{|c|}{ Married men } & \multicolumn{5}{|c|}{ Married women } \\
\hline & Total & Employed & $\begin{array}{c}\text { Not } \\
\text { Empl. }\end{array}$ & Difference & Ratio & Total & Employed & $\begin{array}{c}\text { Not } \\
\text { Empl. }\end{array}$ & Difference & Ratio \\
\hline Market work & 35.3 & 43.1 & 2.8 & 40.3 & $6.5 \%$ & 26.4 & 38.2 & 1.5 & 36.7 & $4.0 \%$ \\
\hline Work at home & 9.1 & 7.8 & 14.6 & -6.8 & $187.4 \%$ & 33.5 & 29.8 & 41.1 & -11.3 & $137.7 \%$ \\
\hline Gardening & 4.5 & 3.8 & 7.2 & -3.4 & $188.0 \%$ & 3.4 & 2.5 & 5.3 & -2.8 & $211.0 \%$ \\
\hline Childcare /Parent care & 6.5 & 5.9 & 8.8 & -2.9 & $148.6 \%$ & 15.5 & 12.6 & 21.7 & -9.1 & $172.5 \%$ \\
\hline Sleep & 50.7 & 50.4 & 52.2 & -1.8 & $103.7 \%$ & 50.3 & 49.9 & 51.2 & -1.3 & $102.5 \%$ \\
\hline "Leisure" & 66.4 & 61.0 & 89.1 & -28.2 & $146.2 \%$ & 42.3 & 37.8 & 51.9 & -14.1 & $137.3 \%$ \\
\hline
\end{tabular}


Table 7. Time Use Patterns during Employment Periods by Employment Span

(mean weekly hours)

\begin{tabular}{|c|c|c|c|c|c|c|}
\hline \multirow{2}{*}{$\begin{array}{c}\text { Employment } \\
\text { span } \\
\text { (rounds) }\end{array}$} & $\begin{array}{c}\text { Number of } \\
\text { observations }\end{array}$ & $\begin{array}{c}\text { Married Men } \\
\text { work }\end{array}$ & $\begin{array}{c}\text { Sleep+ } \\
\text { leisure }\end{array}$ & $\begin{array}{c}\text { Number of } \\
\text { observations }\end{array}$ & $\begin{array}{c}\text { Market } \\
\text { work }\end{array}$ & $\begin{array}{c}\text { Sleep+ } \\
\text { leisure }\end{array}$ \\
\hline & 232 & 48.2 & 108.9 & 207 & 43.1 & \\
4 & 171 & 49.3 & 106.4 & 150 & 89.8 \\
3 & 101 & 50.3 & 107.0 & 80 & 39.8 & 91.3 \\
2 & 46 & 51.0 & 99.7 & 56 & 37.0 \\
1
\end{tabular}


Table 8. The Effect of the Employment Spell on the Allocation of Time of Russian Married Men and Women 1994-1998

4- year cross-section regressions

\begin{tabular}{|c|c|c|c|c|c|c|c|c|}
\hline & \multicolumn{4}{|c|}{ Married Men } & \multicolumn{4}{|c|}{ Married Women } \\
\hline & \multicolumn{2}{|c|}{ Market work } & \multicolumn{2}{|c|}{ Leisure+sleep } & \multicolumn{2}{|c|}{ Market work } & \multicolumn{2}{|c|}{ Leisure+sleep } \\
\hline & $\mathrm{b}$ & $\mathrm{T}$ & $\mathrm{b}$ & $t$ & $\mathrm{~b}$ & $t$ & $\mathrm{~b}$ & $\mathrm{t}$ \\
\hline Schooling & 0.145 & 1.06 & -0.191 & -1.18 & 0.023 & 0.16 & 0.026 & 0.12 \\
\hline Age & 0.077 & 0.21 & 1.130 & 2.67 & 1.216 & 3.51 & -1.324 & -2.58 \\
\hline $\mathrm{Age}^{\wedge} 2$ & -0.002 & -0.37 & -0.012 & -2.49 & -0.015 & -3.55 & 0.016 & 2.54 \\
\hline no. young cld & 0.160 & 0.20 & -2.805 & -2.98 & -2.136 & -2.55 & -5.114 & -4.09 \\
\hline no. old cld & 0.293 & 0.59 & -1.281 & -2.17 & -1.077 & -2.42 & -1.821 & -2.74 \\
\hline Urban & -0.606 & -0.76 & 4.165 & 4.39 & 1.820 & 2.57 & 2.885 & 2.73 \\
\hline Spouse hours & 0.005 & 0.28 & 0.120 & 6.75 & 0.004 & 0.28 & 0.096 & 4.88 \\
\hline Year 1995 & 0.450 & 0.46 & 2.083 & 1.80 & -0.559 & -0.63 & 2.544 & 1.93 \\
\hline Year 1996 & 1.070 & 1.07 & 0.739 & 0.62 & -1.024 & -1.15 & 4.054 & 3.06 \\
\hline Year 1998 & -2.214 & -2.14 & 5.673 & 4.57 & -3.328 & -3.62 & 8.307 & 6.02 \\
\hline Empl 4 & -0.813 & -1.00 & 0.738 & 0.76 & 1.386 & 1.91 & -1.769 & -1.64 \\
\hline Empl 2 & -0.167 & -0.14 & 0.101 & 0.07 & -1.572 & -1.38 & -1.133 & -0.67 \\
\hline Empl 1 & -1.442 & -0.64 & -2.501 & -0.93 & -3.428 & -1.94 & 3.514 & 1.34 \\
\hline Constant & 47.410 & 6.28 & 69.543 & 7.44 & 18.529 & 2.61 & 102.823 & 9.54 \\
\hline adj R sq & \multicolumn{2}{|c|}{0.004} & \multicolumn{2}{|c|}{0.084} & \multicolumn{2}{|c|}{0.037} & \multicolumn{2}{|c|}{0.084} \\
\hline $\begin{array}{l}\text { No. of } \\
\text { observations }\end{array}$ & \multicolumn{2}{|c|}{1661} & \multicolumn{2}{|c|}{1661} & \multicolumn{2}{|c|}{1476} & & \\
\hline
\end{tabular}


Table 9. The Effect of Interruptions in the Employment Career on the Change in Market Hours and Leisure 1994-1998

\begin{tabular}{|c|c|c|c|c|c|c|c|c|}
\hline & \multicolumn{4}{|c|}{ Married Men } & \multicolumn{4}{|c|}{ Married Women } \\
\hline & \multicolumn{2}{|c|}{ Market work } & \multicolumn{2}{|c|}{ Leisure } & \multicolumn{2}{|c|}{ Market work } & \multicolumn{2}{|c|}{ Leisure } \\
\hline & $\mathrm{b}$ & $\mathrm{t}$ & $\mathrm{b}$ & $\mathrm{t}$ & $\mathrm{b}$ & $\mathrm{t}$ & $\mathrm{b}$ & $\mathrm{t}$ \\
\hline Not employed in 1996 & 2.173 & 0.4 & -6.774 & -1.03 & 5.392 & 0.83 & -4.908 & -0.53 \\
\hline Not employed in 1995-96 & -9.404 & -0.71 & 19.308 & 1.21 & -5.420 & -0.36 & 10.835 & 0.50 \\
\hline Change in no. young cld & 1.527 & 0.58 & -6.298 & -1.98 & 1.443 & 0.56 & -6.276 & -1.71 \\
\hline $\operatorname{adj} \mathrm{R} \mathrm{sq}$ & 0 & & 0.012 & & 0.004 & & 0.012 & \\
\hline Change in mean weekly & & & & & & & & \\
\hline Hours & -1.950 & & 7.505 & & -2.150 & & 7.537 & \\
\hline No. of observations & 321 & & 321 & & 273 & & 273 & \\
\hline
\end{tabular}


Table 10. The Effect of Changes in the Employment Rate on the Allocation of Time of Married Couples -Russia 1994-1998

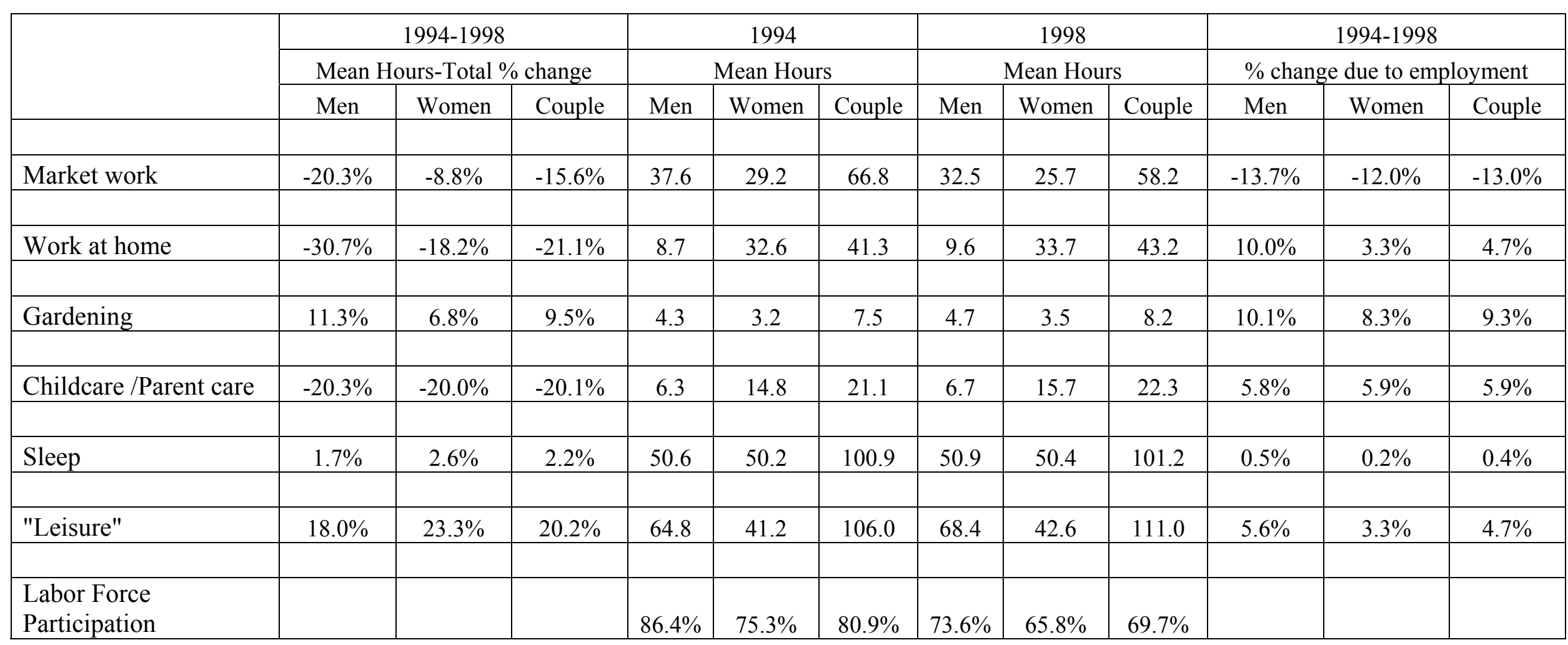

Comments: Columns 1-3 are based on table 2. The computations in columns 4-9 are based on the standardized 4-year means for the employed and not-employed reported in table 6 , where the weight assigned to the employed is the labor fore participation rates reported at the bottom of the table. 


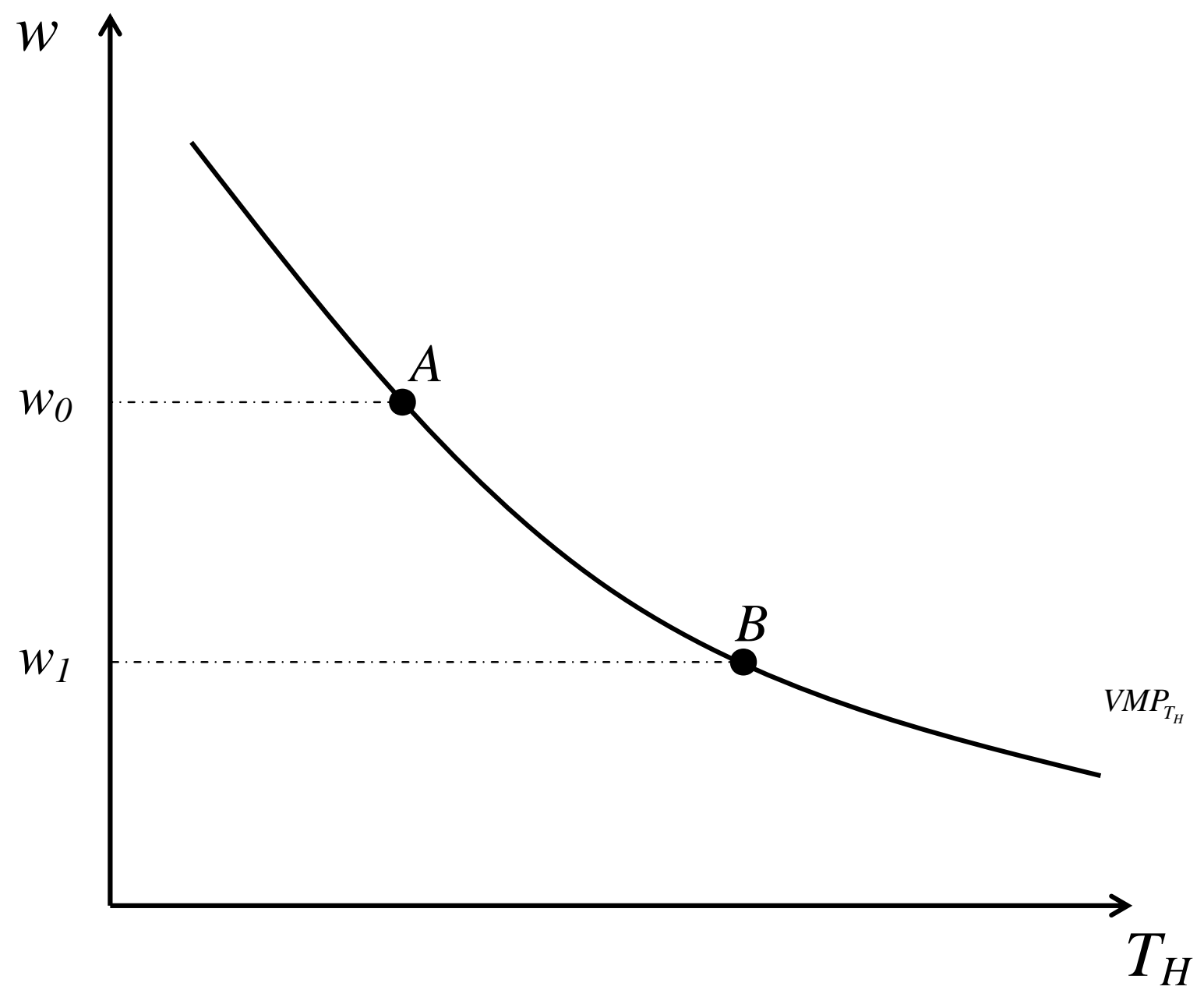

Figure 1 


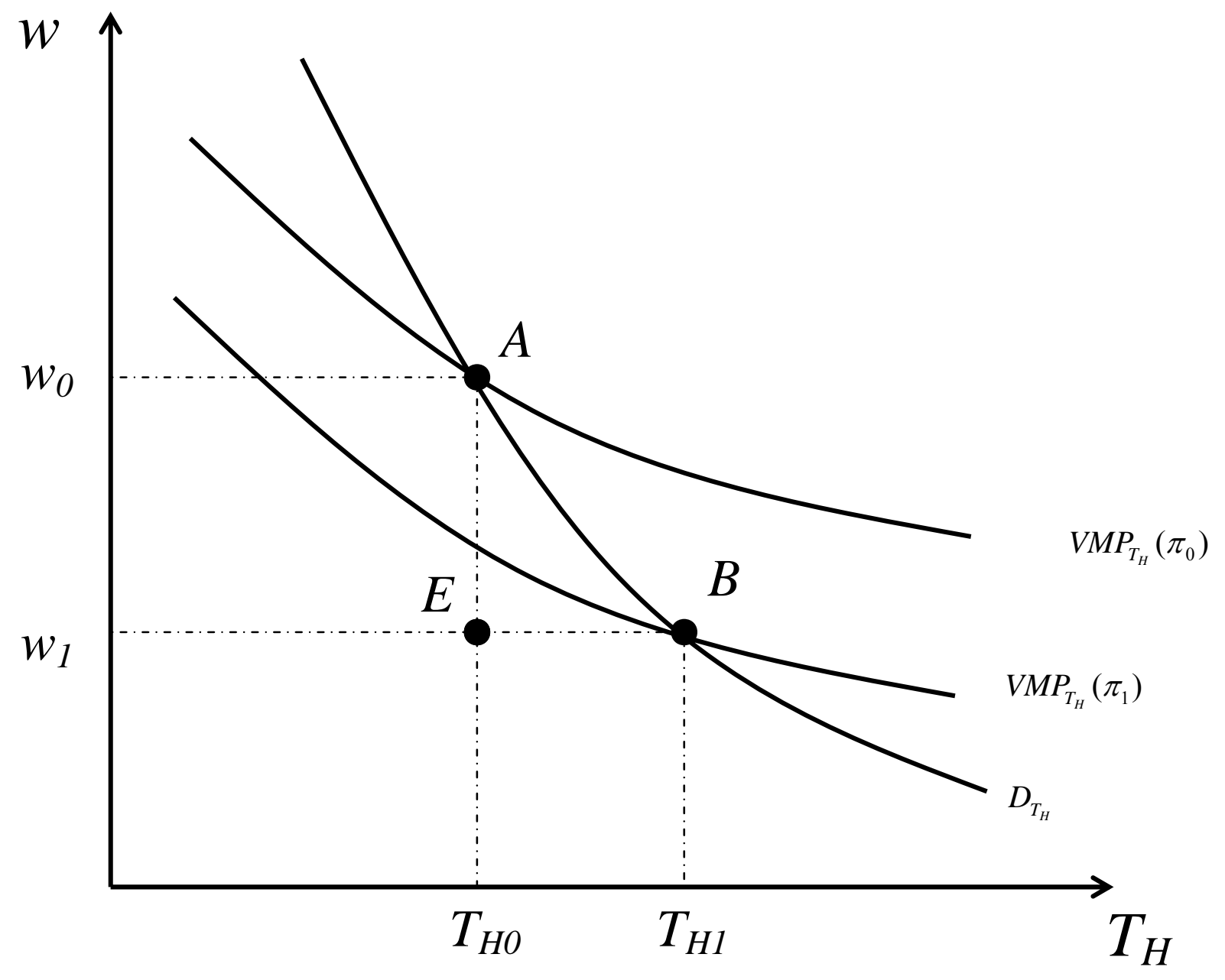

Figure 2 